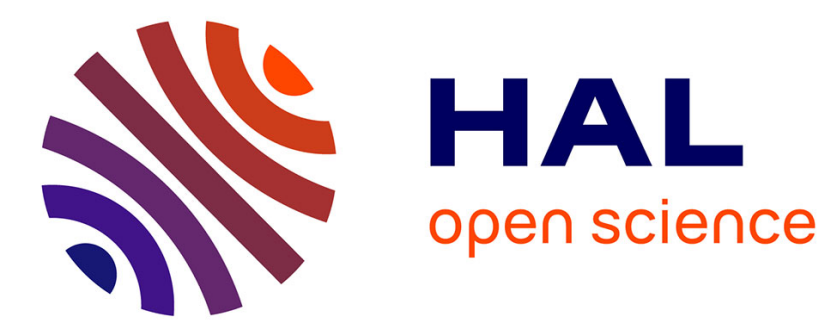

\title{
Humusica 1, article 3: Essential bases - Quick look at the classification
}

\author{
Augusto Zanella, Jean-François Ponge, Rein de Waal, Chiara Ferronato, \\ Maria de Nobili, Jérôme Juilleret
}

\section{- To cite this version:}

Augusto Zanella, Jean-François Ponge, Rein de Waal, Chiara Ferronato, Maria de Nobili, et al.. Humusica 1, article 3: Essential bases - Quick look at the classification. Applied Soil Ecology, 2018, 122 (Part 1), pp.42-55. 10.1016/j.apsoil.2017.05.025 . hal-01658526

\section{HAL Id: hal-01658526 https://hal.science/hal-01658526}

Submitted on 7 Dec 2017

HAL is a multi-disciplinary open access archive for the deposit and dissemination of scientific research documents, whether they are published or not. The documents may come from teaching and research institutions in France or abroad, or from public or private research centers.
L'archive ouverte pluridisciplinaire HAL, est destinée au dépôt et à la diffusion de documents scientifiques de niveau recherche, publiés ou non, émanant des établissements d'enseignement et de recherche français ou étrangers, des laboratoires publics ou privés. 


\section{Humusica 1, article 3: Essential bases - Quick look at the classification}

Augusto Zanella ${ }^{a, *}$, Jean-François Ponge ${ }^{b}$, Rein de Waal ${ }^{c}$, Chiara Ferronato ${ }^{d}$, Maria De Nobilie, Jérôme Juilleret ${ }^{\dagger}$

a University of Padua, Padua, Italy

${ }^{\mathrm{b}}$ Muséum National d'Histoire Naturelle, Paris, France

${ }^{c}$ University of Wageningen, Wageningen, The Netherlands

${ }^{\mathrm{d}}$ University of Bologna, Bologna, Italy

e University of Udine, Udine, Italy

${ }^{\mathrm{f}}$ Luxembourg Institute of Science and Technology, Belvaux, Luxembourg

Keywords: Humus; Humus classification; Terrestrial humus systems; Histic humus systems; Aqueous humus systems; Para humus systems; Anthropogenic humus systems

\section{ABSTRACT}

Terms and concepts have been defined in Humusica 1, article 1 and the functioning of humus systems has been discussed in Humusica 1, article 2. Here a short overview of the matter, showing humus systems in their environment, is provided for beginners, before making field investigations. The present work is intended as a part of the field manual (Humusica 1 and 2), an illustrated, easy-touse application tool for humus systems classification, helpful even for not (yet) expert pedologists. The present article gives also a fast look at the classification, sharing Terrestrial, Histic, Aqueous and Para humus systems, every group being defined by its characteristics set in synthetic tables, and suggests a step-by-step approach allowing everyone to classify and investigate humus systems and forms.

\footnotetext{
* Corresponding author.

E-mail addresses: augusto.zanella@unipd.it (A. Zanella), ponge@mnhn.fr (J.-F. Ponge), rein.dewaal@wur.nl (R. De Waal), chiara.ferronato2@unibo.it (C. Ferronato), maria.denobili@uniud.it (M. De Nobili), Jerome.juilleret@list.lu (J. Juilleret).
} 


\section{Quick look at the classification}

Darwin (1881) described the first Mull humipedon. He discovered that earthworms tilled a grassland soil and could sink boulders, building a true "vegetable mould". Müller (1889) related humipedon, vegetation and soil, describing the first humus forms. In the same period, Dokuchaev (1889) published a famous soil-vegetation zonation in Russia. Hesselmann (1926), Hartmann (1944), Kubiëna (1953), von Mückenhausen (1962), Babel (1971), Delecour and Kindermans (1977) described the morphology and ecology of specialized humus types (the upper part of a soil profile which is enriched in organic matter) in central Europe. With similar ecological approaches, but in wet environments, Jongerius and Pons (1962) and Levesque et al. (1980) proposed a classification of Histic soil horizons and peats. Jenny (1941) proposed an historical formula relating soil genesis and main ecological factors. Duchaufour (1960) and Scheffer et al. (1982) linked humus types, pedogenesis and soil classification. Bornebusch (1930), Omodeo (1950), Marcuzzi (1970), Wallwork (1970), Bouché (1972), Leadley Brown (1978), Bal (1982), Satchell (1983), Clarholm (1985), Ponge (1985), Paoletti (1988), Cluzeau and Fayolle (1988), Martin and Marinissen (1993), Fitter and Garbaye (1994), Bernier and Ponge (1994), Aerts (1997), Brauman (2000), Brown et al. (2000), Cole et al. (2002), Berg and McClaugherty (2003), Van der Heijden et al. (2008), Ponge et al. (2010), Blouin et al. (2013), Cluzeau et al. (2014), Ponge (2015) related ecological groups of soil animals with climatic conditions, phytocoenoses, bacteria, fungi, litter biodegradation stages and even anthropogenic land transformation and agriculture. In parallel, Dell'Agnola and Nardi (1987), Stevenson (1972, 1994), Piccolo $(1996,2001)$ and Kumada, 1988 focused on physical, chemical and biological properties of humic components of humipedons. All these researches and a huge number of synthesis books, such as Killham (1994), Benckiser et al. (1997), Gobat et al. (1998), Lavelle and Spain (2001), Sterner and Elser (2002), Ponge (2003), Coleman et al. (2004), Bardgett et al. (2005), Eldor et al. (2007), Legros (2007), Citeau et al. (2008) and Wall et al. (2012), nourished the idea of a more biological/ecological concept of soil. Following the way traced by the pioneers of the topsoil morpho-functional classification (Darwin, Müller, Dokuchaev, Jenny, Hesselmann, Hartmann, Kubiëna, Babel, Delecour and Kindermans, Jongerius and Pons, Duchaufour, Levesque, Scheffer) a series of field manuals were progressively published by Toutain (1981), Green et al. (1993), Brêthes et al. (1995), von Nestroy et al. (2000), Zanella et al. (2001), Jabiol et al. (2004), Broll et al. (2006), Van Delft et al. (2007), Jabiol et al. (2009) and Zanella et al. (2006, 2009, 2011), in order to enrich soil classifications with main features ofbiological horizons.

The present classification has been conceived around forest soils, for which more information and historical datasets are available, and for soils of grasslands, pastures and wetland areas, with negligible to strong human impact. Originally it was not suited to tilled agro-ecosystems, because tillage periodically destroys the "natural" organization and radically alters the functioning of surface horizons. Recently we considered the possibility to apply our system of classification even to anthropogenic soils, with the purpose of comparing their morpho-functional properties to those of more natural soils. In the long run, the final goal might be to decrease the functional distance between exploited and natural soils, by comparing them and adjusting properties of the former at regular intervals, thereby ensuring the incessancy of their ecosystemic functions and a sustainable production of food. The authors of this manual propose a classification of anthropogenic Agro 
(agricultural, modified from natural humus systems) and Techno humus systems (artificial, newly man-made) as a tool for monitoring and managing exploited soils.

The humus form classification is based on the sequence and morphological characteristics, including morphological evidence of biological activity, of organic and/or organic-mineral soil horizons observed and described in the field. In some cases, a few basic chemical data $\mathrm{pH}$, organic carbon content) are required. A complete set of diagnostic organic and organic-mineral horizons, which are mutually exclusive, is defined. The classification keys use diagnostic horizons and other complementary humipedon (humus profile) or environmental data. These last complementary data are not part of the classification, but can help in circumscribing the classified units and understanding their peculiar functioning. Every mineral horizon cited in this paper has been classified and named using the manual of the Guidelines for Soil Classification (FAO, 2006).

The classification consists in a scheme that tries avoiding strict cleavages between soil types, allowing intergrades to be classified. A first look at the surface of our planet allows distinguishing:

- well-drained soils (Terrestrial humus systems, potentially forest/shrub/grassland ecosystems);

- wet soils (Histic humus systems, potentially forest/shrub or aquatic plants ecosystems; Aqueous, sea tidal zones and sea beds);

- intergrades (dry Histic = Epihisto Histic humus systems; wet Terrestrial = Hydro Terrestrial humus systems);

- other natural soils (Para humus systems: soil systems strongly influenced by archaea = Archaeo; soil systems strongly influenced by anaerobic bacteria = Anaero; soil systems strongly influenced by lichens, algae, fungi =Crusto; soil systems strongly influenced by mosses = Bryo; soil systems strongly influenced by fern, grass, ericaceous root systems = Rhizo; soil systems strongly influenced by organisms living in decaying wood= Ligno);

- anthropogenic soils (Agro: natural soils transformed for agricultural and sylvicultural purposes; Techno: new man-made humus systems).

Terrestrial humus systems correspond to humus forms in which faunal activities and decomposition of organic matter are well visible and occur in aerated conditions, never submersed and/or water-saturated, or only for a few days per year (Fig. 1, Table 1). Non hydromorphic organic $(\mathrm{O})$ and organic-mineral soil horizons (A or $\mathrm{AE}$ ) characterize these forms.

Histic humus systems correspond to humus forms in which faunal activities and decomposition of organic matter are well visible but are or have been strongly limited and/or influenced by anaerobic conditions (Fig. 1, Table 2). They are submersed and/or water-saturated for many months (usually more than 6 months per year). Organic-mineral (anA) or organic (H) soil horizons characterize these forms.

Prefixes are used to resolve transitional forms between aerobic (Terrestrial) and anaerobic (Histic) conditions: 
- Hydro is used as a prefix when some hydromorphic horizons (denoted by the prefix " $\mathrm{g}$ ") are present in Terrestrial humus forms, example Hydro Mull, Hydro Eumull, Hydro Dysmoder.

- Epihisto is used as a prefix for intergrades between Terrestrial and Histic humus forms when terrestrial hydromorphic horizons (prefix " $\mathrm{g}$ ") are combined with Histic horizons (anA and/or H), example Epihisto Anmoor, Epihisto Euanmoor, Epihisto Limisaprimoor.

Each humus system is composed of 3-4 humus forms listed in the following descriptions of Terrestrial and Histic systems:

TERRESTRIAL: Humus systems in which faunal activities and decomposition of organic matter are well visible and occur in aerated conditions (Fig. 2, Table 1):

- Humus system in which faunal activities and decomposition of organic matter are strongly limited by cold and/or acid conditions: MOR (humus forms: Hemimor, Humimor, Eumor);

- Humus system in which biological activities and decomposition of organic matter are moderately limited by low temperature and/or acidity conditions: MODER (humus forms: Hemimoder, Eumoder, Dysmoder);

- Humus system in which faunal activities and decomposition of organic matter are weakly or not limited by environmental constraints: MULL (humus forms: Eumull, Mesomull, Oligomull, Dysmull);

- Humus system in which faunal activities and decomposition of organic matter are strongly influenced by seasonally contrasted dry or cold climate conditions: AMPHI (humus forms: Leptoamphi, Eumacroamphi, Eumesoamphi, Pachyamphi);

- Humus system in which faunal activities and decomposition of organic matter are strongly limited by mountain climate on calcareous hard substrate (lithopedon): TANGEL (humus forms: Leptotangel, Eutangel, Pachytangel).

Terrestrial humus systems and forms are presented in the following articles of Humusica 1:

- Article 4: Terrestrial - Specific terms and diagnostic horizons;

- Article 5: Terrestrial - Keys of classification of systems and forms;

- Article 6: Terrestrial - Hydro intergrades.

HISTIC: Humus systems in which the transformation of organic matter by fauna (comminution of plant material, faecal deposition) and microbes (darkening, softening of plant material) is still visible but is or has been strongly limited and/or influenced by anaerobic conditions favoured by prolonged periods of water saturation by groundwater (Fig. 3, Table 2):

- Humus system of wet very base-poor soils in brook valley systems and bogs: FIBRIMOOR (humus forms: Saprifibrimoor, Humifibrimoor, Eufibrimoor);

- Humus system of wet moderately base-poor soils in brook valley systems, or base-enriched soils of drained previously base-poor bogs: MESIMOOR (humus forms: Saprimesimoor, Humimesimoor, Eumesimoor, Fibrimesimoor)

- Humus system of moist (with less water than "wet") moderately base-poor soils in brook valley systems or base-rich soils in half-drained fens: AMPHIMOOR (humus forms: Humiamphimoor, Mesiamphimoor, Fibriamphimoor); 
- Humus system of moist base-rich soils in brook valley systems or fens (large extended systems characterized by a dominant process of sedimentation, large floodplains): SAPRIMOOR (humus forms: Limisaprimoor, Eusaprimoor, Oligosaprimoor);

- Humus system of wet base-rich soils or soils enriched by base-rich groundwater in brook valley systems (small rivers, brooks, small streams and floodplains, not in dynamic floods or inundations with fast currents): ANMOOR = (humus forms: Euanmoor, Limianmoor, Saprianmoor).

Histic humus systems and forms are presented in the following articles of Humusica 2:

- Article 9: Histic - Specific terms and diagnostic horizons;

- Article 10: Histic - Keys of classification of systems and forms;

- Article 11: Histic - Epihisto intergrades.

AQUEOUS: Tidal and subtidal humus systems in which the transformation of organic matter by fauna (comminution of plant material, faecal deposition) and microbes (darkening, softening of plant material) is still visible but is or has been strongly limited and/or influenced by anaerobic conditions (Fig. 4):

- Humus system in tidal zone (between low and high tide zone): TIDAL = (Oxitidal, Reductitidal);

- Humus system under tidal zone (under low tide line): SUBTIDAL = (Eusubtidal).

Aqueous humus systems (Table 3) are presented in Humusica 2, article 12: Tidal and Subatidal humus systems and forms.

Environmental contexts of Terrestrial, Histic and Aqueous humus systems are schematized in Tables 1-3, respectively.

The ecological determinants of PARA humus systems are different from those of the main systems. Para systems can be present in the absence of soil and are strongly related to specific habitats and/or plant covers:

- Biological crusts on rock or soil: CRUSTO;

- Moss cushions or arbuscular lichens: BRYO;

- Root mats: RHIZO;

- Decaying wood: LIGNO;

- Humus systems and biological crusts in submerged photic habitats (exposed to sunlight and thus permitting photosynthesis; usually less than $100 \mathrm{~m}$ in depth): ANAERO (considered as a first stage of a more evolved Aqueous);

- Humus systems and biological crusts in submerged photic extreme habitats, such as volcanoes, above a persistent heat source, water in contact with pyroclastic flows, fumaroles), or in submerged aphotic zones (deep seas, hot submerged sources, colonies of barophile organisms...):ARCHAEO.

Para humus systems are briefly presented in Table 4. Each system is subdivided in humus forms defined by specific diagnostic horizons described in Humusica 2, article 13: Para humus systems. 
AGRO are humus systems transformed by human practices in which diagnostic horizons of natural humus systems are still observable.

TECHNO are humus systems transformed by human practices in which diagnostic horizons of natural humus systems are no longer observable, although natural processes can be still in play. Three subsystems are distinguished according to the degree of artificiality:

- Man-made humus systems, with recognizable and assignable to comparable natural humus horizons: MANURE HUMUS;

- Man-made humus systems without visible by the naked eye humus horizons: SOIL-FREE HUMUS;

- Man-made humus systems corresponding to waste deposits with humus horizons not assignable to known Terrestrial, Histic, Aqueous or Para natural humus horizons: DUMP HUMUS.

In Humusica 2, article 14 we review knowledge about anthropogenic soils, before presenting anthropogenic humus systems in Humusica 2, articles 15 (Agro = agricultural humus systems) and 16 (Techno $=$ man made humus systems). Table 5 shows a brief characterisation of these systems.

\section{Step-by-step classification}

The classification of humus systems and forms is based on the identification of diagnostic horizons, which are composed of basic, well-identified belowground components.

In the field, the following steps are necessary for classifying humus systems and forms:

- a humus profile (humipedon) has to be dug out. For usual investigations, a hole of $50 \times 50 \times$ $50 \mathrm{~cm}$ is sufficient. Vegetation heterogeneity and scale of observation have to be considered and are illustrated in Humusica, 1, article 7;

- all organic horizons and the underlying organic-mineral horizons have to be made visible; generally, even mineral horizons are investigated to have a better assessment of the soil type, as in Fig. $5(100 \times 100 \times 100-120 \mathrm{~cm})$;

- all present diagnostic horizons (usually $2-5$ horizons) of the profile must be identified; the description of each potential diagnostic horizon is given in Humusica 1, article 4 for Terrestrial humus forms and Humusica 2, articles 9 and 12 for Histic and Aqueous humus forms, respectively: compare the real horizon with the illustrated description;

- to a list of diagnostic horizons corresponds a precise humus form, which is included in a particular humus system. The assignment could be easily done using the practical tables furnished in the abovementioned articles.

Facultative qualifiers in use in the Word Reference Base soil classification system (IUSS Working Group WRB, 2015) may be added between brackets to the names of humus systems or forms. A list of applicable WRB topsoil qualifiers is proposed in Appendix A. 
The classification of humus forms is a step-by-step process starting from the hierarchically upper humus systems, these being easier to identify than humus forms.

\subsection{First step: select the right environmental context}

Rough evaluation of the main humus system corresponding to a given environmental context:

Unusual humus systems (atypical, made by algae, mosses, on rocks, bark, cold, dry hard environments, a lot of roots or wood...) are Para systems (Fig. 6a-d).

Wet soils, peats, when you need boots for accomplishing your investigation, there is water here and there, boots dip into the soil as into a sponge; if vegetation cover, then hydrophilic vegetation is present: Histic humus systems (Fig. 7a and b) or sea sides Aqueous humus systems (Fig. $8 a$ and $b)$.

Dry "usual" soils, forest soils dwelled by not hydrophilic vegetation: Terrestrial humus systems (Fig. 9a and b).

Agricultural crop fields, urban soils or artificial humus systems (compost, mulch other manures): Agro (Fig. 10a-c) or Techno (Fig. 11) humus systems.

\subsection{Second step: select the right humus system}

This step is the most important point of the classification. Each humus system (abbreviated from humus interaction system, see Humusica 1 , article 1 for more details about concepts and vocabulary) is characterized by a specific morpho-functional structure. The concept of interaction system (Jagers op Akkerhuis, 2008) gives fundamental knowledge for eventual further ecological investigation or management counselling. According to this author, an interaction system is an association between several interactive components which is endowed with properties not explained by any of its unit components, i.e. it is another definition of emergent properties sensu Ponge (2005). In Fig. 1 there are general indications related to water dynamics, parent material (or lithopedon) and biological activity. The parent material is a crucial factor in the case of Terrestrial humus systems, and water dynamics is essential in the genesis of Histic systems. Moreover, biological activity, which is directly related to the rate of litter biodegradation (low rate =accumulation of non-biodegraded litter) shows a gradient from fast to slow humus systems as follows:

- in Terrestrial systems (Fig. 2): 1) on base-rich substrate: Mull > Amphi > Tangel, or 2) on basepoor substrate: Mull > Moder > Mor;

- in Histic systems (Fig. 3): 1) in small wet systems: Anmoor > (Amphimoor or Mesimoor) > Fibrimoor, or 2) in wide wet systems: Saprimoor $>$ (Amphimoor or Mesimoor) $>$ Fibrimoor. 
- in Aqueous systems (sea sides, Fig. 4), shallow-tidal > deep-tidal > sub-tidal, corresponding to: Oxitidal > Reductitidal > Eusubtidal humus form references.

In this manual, after the description of each diagnostic horizon that can be observed in the field, we propose a step-by-step classification key of humus systems (see $\S 1$ ) based on presence/absence and relative thickness of these horizons. Practical tables for Terrestrial and Histic humus systems, showing series of diagnostic horizons, have been set for field survey and are described in Humusica 1, articles 5 and 10, respectively. A detachable dichotomous version of a key for Terrestrial humus forms is reported in Humusica 1, article 5. An iPhone application (Terrhum) will be also available, allowing determining the right Terrestrial humus forms after answering a series of yes/no questions about illustrated diagnostic horizons.

\subsection{Third step: select the right humus form}

A more precise identification is possible by identifying diagnostic horizons and measuring their thickness when present. Each humus form corresponds to a precise series of diagnostic horizons, well defined in their structural components. Even the thickness of the "boundary layer" between superposed horizons is often important for the classification. The structure of the organicmineral horizon plays a master role (Fig. 12).

The phase of survey of the humus profile is crucial, very precise data have to be noted in the field. The space-time scale of variation of humus forms is smaller than that of the humus system. A humus system could be associated to a single forest type (single management type), or to a single vegetation type, covering hectares for centuries. A humus form is related to local variations at the level of plant cover heterogeneity (ex. a humus form may be present under a tree differing from another form in an open area of the same forest stand), covering often less than one are, and possibly changing within a few decades.

Practical tools like blades, knives, shovels, sieves, little pickaxes, $\mathrm{pH}$ meters or indicators, $\mathrm{HCl}$ (10\%), Munsell soil colour charts, magnifying lenses, keys for soil fauna, humus systems, soil and geological maps or manuals, cameras and plastic bags for samples are generally in the bag of a humus system specialist and are necessary for a correct humus form identification (Fig. 13a-f).

\subsection{Fourth step (facultative): select the right qualifier}

As complementary coded information, a series of qualifiers in accordance with the World Reference Base soil classification system (IUSS Working Group WRB, 2015) can be used. When possible, these qualifiers have to be added between brackets to the name of each humus form, preceded by WRB 2015 and in alphabetical order. Some useful WRB qualifiers for humus form description are shown in Appendix A. 
In IUSS Working Group WRB (2015), the qualifiers are written with capital letters when used for soil WRB references (e.g. Chernic), or with lowercase letters when used for diagnostic horizons, properties and materials (e.g. chernic horizon).

Examples:

- Dysmull (WRB 2015: Dolomitic, Dystric)

- Eumoor (WRB 2015: Arenic, Floatic).

\section{Appendix A. Supplementary data}

Supplementary data associated with this article can be found, in the online version, at http://dx.doi.org/10.1016/i.apsoil.2017.05.025.

\section{References}

Aerts, R., 1997. Climate: leaf litter chemistry and leaf litter decomposition in terrestrial ecosystems: a triangular relationship. Oikos 79, 439-449.

Babel, U., 1971. Gliederung und Beschreibung des Humusprofils in mitteleuropäschen Wäldern. Geoderma 5, 297-324.

Bal, L., 1982. Zoological Ripening of Soils. Pudoc, Wageningen.

Bardgett, R.D., Usher, M.B., Hopkins, D.W., et al., 2005. Biological Diversity and Function in Soils. Cambridge University Press, Cambridge.

Benckiser, G., et al., 1997. Fauna in Soil Ecosystems: Recycling Processes, Nutrient Fluxes, and Agricultural Production. Marcel Dekker, Dordrecht.

Berg, B., McClaugherty, C., 2014. Plant Litter: Decomposition, Humus Formation, Carbon Sequestration. Springer, Berlin.

Bernier, N., Ponge, J.F., 1994. Humus form dynamics during the sylvogenetic cycle in a mountain spruce forest. Soil Biol. Biochem. 26, 183-220.

Blouin, M., Hodson, M.E., Delgado, E.A., Baker, G., Brussaard, L., Butt, K.R., Dai, J., Dendooven, L., Peres, G., Tondoh, J.E., Cluzeau, D., Brun, J.-J., 2013. A review of earthworm impact on soil function and ecosystem services. Eur. J. Soil Sci. 64, 161-182.

Bornebusch, C.H., 1930. The fauna of forest soil. Forstl. Forsøgsv. Danmark. 11, 1-244.

Bouché, M.B., 1972. Lombriciens de France: Écologie et Systématique. Institut National de la Recherche Agronomique, Paris. 
Brêthes, A., Brun, J.J., Jabiol, B., Ponge, J.F., Toutain, F., 1995. Classification of forest humus forms: a French proposal. Ann. Sci. For. 52, 535-546.

Brauman, A., 2000. Effect of gut transit and mound deposit on soil organic matter transformations in the soil feeding termite: a review. Eur. J. Soil Biol. 36, 117-125.

Broll, G., Brauckmann, H.J., Overesch, M., Junge, B., Erber, C., Milbert, G., Baize, D., Nachtergaele, F., 2006. Topsoil characterization: recommendations for revision and expansion of the FAO-draft (1998) with emphasis on humus forms and biological factors. J. Plant Nutr. Soil Sci. 169, 453-461.

Brown, G.G., Barois, I., Lavelle, P., 2000. Regulation of soil organic matter dynamics and microbial activity in the drilosphere and the role of interactions with other edaphic functional domains. Eur. J. Soil Biol. 36, 177-198.

Citeau, L., Bispo, A., Bardy, M. King, et al., 2008. Gestion Durable des Sols. Quae, Versailles.

Clarholm, M., 1985. Interactions of bacteria, protozoa and plants leading to mineralization of soil nitrogen. Soil Biol. Biochem. 17, 181-187.

Cluzeau, D., Fayolle, L., 1988. Impacts sur les lombriciens des traitements pesticides, en particulier cupriques: dans le vignoble champenois. C.R. Acad. Agric. Fr. 74, 109-117.

Cluzeau, D., Descotes, A., Georget, C., Chaussod, R., Nouaim-Chaussod, R., Pérès, G., Guernion, M., Cylly, D., Rougé, L., Garcia, O., Panigai, L., Moncomble, D., 2014. Les sols vivants du vignoble champenois: comment intégrer les connaissances acquises sur ce patrimoine pour contribuer à la pérennité de l'A.O.C Champagne? Rapport Programme GESSOL (MEDDTL \& ADEME).

Cole, L., Bardgett, R.D., Ineson, P., Hobbs, P.J., 2002. Enchytraeid worm (Oligochaeta) influences on microbial community structure: nutrient dynamics and plant growth in blanket peat subject to warming. Soil Biol. Biochem. 34, 83-92.

Coleman, D.C., Crossley, D.A., Hendrix, P.F., 2004. Fundamentals of Soil Ecology, $2^{\text {nd }}$ ed. Academic Press, San Diego.

Darwin, C., 1881. The Formation of Vegetable Mould through the Action of Worms with some Observations on Their Habits. John Murray, London.

Delecour, F., Kindermans, M., 1977. Manuel de Description des Sols. Faculté des Sciences Agronomiques de Gembloux, Gembloux.

Dell'Agnola, G., Nardi, S., 1987. Hormone-like effect and enhanced nitrate uptake induced by depolycondensed humic fractions obtained from Allolobophoru rosea and A. caliginosa faeces. Biol. Fert. Soils 4, 115-118.

Dokuchaev, V.V., 1889. The Zones of Russia. Akademy Nauk, Moscow.

Duchaufour, P., 1960. Précis de Pédologie. Masson, Paris.

Eldor, A.P., et al., 2007. Soil Microbiology, Ecology, and Biochemistry, $3^{\text {rd }}$ ed. Elsevier, Amsterdam.

FAO, 2006. Guidelines for Soil Description, $4^{\text {th }}$ edition. FAO, Rome. 
Fitter, A.H., Garbaye, J., 1994. Interactions between mycorrhizal fungi and other soil organisms. Plant Soil 159, 123-132.

Gobat, J.M., Aragno, M., Matthey, W., 1998. Le Sol Vivant. Bases de Pédologie. Biologie des Sols. Presses Polytechniques et Universitaires Romandes, Lausanne.

Green, R.N., Trowbridge, R.L., Klinka, K., 1993. Towards a taxonomic classification of humus forms. For. Sci. Monogr. 29, 1-49.

Hartmann, F., 1944. Waldhumusformen. Zeitschrift Gesamte Forstw. 76, 39-70.

Hesselmann, H., 1926. Studier över barrskogens humustäcke: dess egenskaper och boroende av skogsvården. Medd. Statens Skogsförsöksanst. 22, 169-552.

IUSS Working W.R.B. Group, 2015. World Reference Base for Soil Resources 2014, update 2015. International soil classification system for naming soils and creating legends for soil maps FAO, Rome.

Jabiol, B., Zanella, A., Englisch, M., Hager, H., Katzensteiner, K., De Waals, R., 2004. Towards a European classification of terrestrial humus forms. Eurosoil Congress, Freiburg, Germany (September), 4-12.

Jabiol, B., Brêthes, A., Brun, J.J., Ponge, J.F., Toutain, F., Zanella, A., Aubert, M., Bureau, F., 2009. Typologie des formes d'humus forestières (sous climats tempérés). In: Baize, D., Girard, M.C. (Eds.), Référentiel Pédologique 2008. Quae, Versailles, pp. 327-355.

Jagers op Akkerhuis, G.A.J.M., 2008. Analysing hierarchy in the organization of biological and physical systems. Biol. Rev. 83, 1-12.

Jenny, H., 1941. Factors of Soil Formation: a System of Quantitative Pedology. McGraw-Hill, New York.

Jongerius, A., Pons, L.J., 1962. Soil genesis in organic soils. Boor Spade 12, 156-177.

Killham, K., 1994. Soil. Cambridge University Press, Cambridge.

Kubiëna, W.L., 1953. Bestimmungsbuch und Systematik der Böden Europas. Enke, Stuttgart.

Kumada, K., 1988. Chemistry of Soil Organic Matter, $1^{\text {st }}$ ed.vol. Elsevier, Amsterdam.

Lavelle, P., Spain, A.V., 2001. Soil Ecology. Kluwer, Dordrecht.

Leadley Brown, A., 1978. Ecology of Soil Organisms. Heinemann, Portsmouth.

Legros, J.P., 2007. Les Grands Sols du Monde. Presses Polytechniques et Universitaires Romandes, Lausanne.

Levesque, M., Dinel, H., Marcoux, R., 1980. Evaluation des critères de différentiation pour la classification de 92 matériaux tourbeaux du Québec et de l'Ontario. Can. J. Soil Sci. 60, 479-486.

Müller, P.E., 1889. Recherches sur les formes naturelles de l'humus et leur influence sur la végétation et le sol. Berger-Levrault, Paris. 
Marcuzzi, G., 1970. La fauna del suolo e il suo significato nel processo di umificazione della lettiera. In: Hartmann, F. (Ed.), Diagnosi degli Humus Forestali su Basi Biomorfologiche. CEDAM, Padova, pp. 190-275.

Martin, A., Marinissen, J.C.Y., 1993. Biological and physico-chemical processes in excrements of soil animals. Geoderma 56, 331-347.

Omodeo, P., 1950. Richerce zoologische sul Massiccio del Pollino (Lucania-Calabria). I. Oligocheti. Ann. Istit. Museo Zool. Univ. Napoli 2, 1-12.

Paoletti, M.G., 1988. Soil Invertebrates in cultivated and uncultivated soils in northeastern Italy. Redia 71, 501-563.

Piccolo, A., 1996. Humic Substances in Terrestrial Ecosystems. Elsevier, Amsterdam.

Piccolo, A., 2001. The supramolecular structure of humic substances. Soil Sci. 166, 810-832.

Ponge, J.F., Zanella, A., Sartori, G., Jabiol, B., 2010. Terrestrial humus forms: ecological relevance and classification. https://hal.archives-ouvertes.fr/hal-00521337 (Accessed 3 April 2017).

Ponge, J.F., 1985. Utilisation de la micromorphologie pour l'étude des relations trophiques dans le sol: la couche $L$ d'un moder hydromorphe sous Pinus sylvestris (Forêt d'Orléans, France). Bull. Ecol. $16,117-132$.

Ponge, J.F., 2003. Humus forms in terrestrial ecosystems: a framework to biodiversity. Soil Biol. Biochem. 35, 935-945.

Ponge, J.F., 2005. Emergent properties from organisms to ecosystems: towards a realistic approach. Biol. Rev. 80, 403-411.

Ponge, J.F., 2015. The soil as an ecosystem. Biol. Fertil. Soils 51, 645-648.

Satchell, J.E., 1983. Earthworm Ecology: from Darwin to Vermiculture. Chapman and Hall, London.

Scheffer, F., Schachtschabel, P., Blume, H.P., Hartge, K.H., Schwertmann, U., 1982. Lehrbuch der Bodenkunde. Enke, Stuttgart.

Sterner, R.W., Elser, J.J., 2002. Ecological Stoichiometry: the Biology of Elements from Molecules to the Biosphere. Princeton University Press, Princeton.

Stevenson, F.J., 1972. Role and function of humus in soil with emphasis on adsorption of herbicides and chelation of micronutrients. Bioscience 22, 643-650.

Stevenson, F.J., 1994. Humus Chemistry: Genesis, Composition, Reactions, $2^{\text {nd }}$ ed. Wiley, Hoboken.

Toutain, F., 1981. Les humus forestiers: structures et modes de fonctionnement. Rev. For. Fr. 33, 449-477.

Van Delft, S.J.P., De Waal, R.W., Kemmers, R., Mekkink, P., Sevink, J., 2007. Field Guide of Humus Forms: Description and Classification of Humus Forms for Ecological Applications. Alterra, Wageningen. 
Van der Heijden, M.G.A., Bardgett, R.D., Van Straalen, N.M., 2008. The unseen majority: soil microbes as drivers of plant diversity and productivity in terrestrial ecosystems. Ecol. Lett. 11, 296310.

von Mückenhausen, E., 1962. Entstehung, Eigenschaften und Systematik der Böden der Bundesrepublik Deutschland. DLG, Frankfurt-am-Main.

von Nestroy, O., Danneberg, O.H., Englisch, M., Geszl, A., Hager, H., Herzberger, E., Kilian, W., Nelhiebl, P., Pecina, E., Pehamberger, A., Schneider, W., Wagner, J., 2000. Systematische Gliederung der Boden Österreichs (Österreichische Bodensystematik 2000). Mitt. Öster. Bodenkundl. Ges. 60, 1124.

Wall, H.D., et al., 2012. Soil Ecology and Ecosystems Services. Oxford University Press, Oxford.

Wallwork, J.A., 1970. Ecology of Soil Animals. McGraw-Hill, London.

Zanella, A., Tomasi, M., de Siena, C., Frizzera, L., Jabiol, B., Nicolini, G., Sartori, G., Calabrese, M.S., Mancabelli, A., Nardi, S., Pizzeghello, D., Odasso, M., 2001. Humus Forestali. Centro di Ecologia Alpina, Trento.

Zanella, A., Englisch, M., Jabiol, B., Katzensteiner, K., Van Delft, B., Hager, H., De Waal, R., Graefe, U., Brun, J.J., Chersich, Broll, S., Kolb, G., Baier, R., Baritz, R., Langhor, R., Cools, R., Wresowar, N., Milbert, M., Ponge, J.F., 2006. Towards a common humus form classification, a first European approach: few generic top soil references as functional units. Poster presented at the $18^{\text {th }}$ Congress of Soil Science, Philadelphia, July 9-15, 2006.

Zanella, A., Jabiol, B., Ponge, J.F., Sartori, G., De Waal, R., Van Delft, B., Graefe, U., Cools, N., Katzensteiner, K., Hager, H., English, M., Brêthes, A., 2009. Toward a European Humus Forms Reference Base. Studi Trent. Sci. Nat. 85, 145-151

Zanella, A., Jabiol, B., Ponge, J.F., Sartori, G., De Waal, R., Van Delft, B., Graefe, U., Cools, N., Katzensteiner, K., Hager, H., Englisch, M., 2011. A European morphofunctional classification of humus forms. Geoderma 164, 138-145. 


\section{Figure captions}

Fig. 1. Panorama of Terrestrial, Histic and Aqueous humus systems, with their main ecological determinants and diagnostic horizons. Hydro and Epihisto are prefixes used in transitional cases. Hydro is adopted as a prefix when $\mathrm{gOH}, \mathrm{gA}$ or gAE horizons are present in Terrestrial humus profiles even without other diagnostic horizons; Epihisto is adopted as a prefix when gA or gAE are present (gOL, gOF and gOH possible but not sufficient) in Histic humus profiles (= in addition to anA or $\mathrm{H}$ horizons).

Fig. 2. Simplified scheme of Terrestrial humus systems classification. The scheme shows main climatic and parent material determinants (top of the picture), diagnostic horizons (middle) and biological actors of organic matter transformation (bottom). OL, OF, nozOF, OH, maA, miA, nozA: diagnostic horizons described in Humusica 1, article 4; transition between $\mathrm{OH}$ and $\mathrm{A}$ horizons: dashed line =gradual, continuous line= sharp; $\mathrm{A}$ horizon aggregates: two lines $=$ non zoogenic; small black circles = biomicrostructured; white small circles = biomesostructured; large white circles =biomacrostructured; lithopedon: bricks = base-rich substrate, $+=$ basepoor substrate; Pachy: thick, Eu: typical; Dys: acid; Humi: rich in undecayed organic matter; Eumacro and Eumeso: large or medium biogenic structures in the A horizon, as reported in Humusica, article 4. Humps and troughs of the continuous blue line refer to the hypothesis of humus systems as ecological attractors, with Mull as "final' attractor, as detailed in Zanella et al. (2001), Ponge (2003), Zanella et al. $(2006,2009)$ and Humusica 1, articles 2, 4, 7 and 8. Figure authors: Zanella A., Ponge J.F.

Fig. 3. Simplified scheme of Histic humus systems classification. The scheme shows ground and water table levels (top of the picture), main diagnostic horizons and biological actors of organic matter transformation along a gradient of increasing base saturation and decreasing contribution rainwater. For the definition of diagnostic horizon codes of Histic humus systems the reader is referred to Humusica 2, article 9. Figure authors: Waal de R., Zanella A., Ponge J.F.

Fig. 4. Simplified scheme of Aqueous humus systems classification. The scheme shows high and low tide levels, Munsell colours of main horizons and biological actors of organic matter transformation. Figure authors: Ferronato C., De Nobili M, Zanella A., Ponge J.F.

Fig. 5. Example of a hole dug for the observation of the humus profile in a beech forest in Trentino (Italy). Humus system: Amphi; Humus form: Biomesoamphi; Soil: dystric Cambisol (IUSS Working Group WRB, 2015). To the left are concepts used in the classification of humus systems and forms (diagnostic horizons with their letter coding). To the right are real objects as they can be observed by a naive field observer (humus horizons of varying colour and depth, humus profile).

Fig. 6. Para humus systems. Examples of a) Crusto, covering a granitic wall, b) Bryo, developing on a rocky substrate, c) Rhizo, under a grassland covering a Leptosol and d) Ligno systems taking place in correspondence to woody cumulus or stumps under biodegradation.

Fig. 7. Histic humus systems. Example of a) Anmoor or b) Amphimoor systems environments at the edge of a little lake in French Brittany (Station Biologique de Paimpont, France). 
Fig. 8. Aqueous humus systems. a) Subtidal system environment. Typical inner salt marsh landscape (Martignano island, Grado and Marano Lagoon, northern Adriatic sea, Italy). The various and closely spaced plant communities and soils with different hydroperiods are caused by the presence of small creeks (ghebi) and depressions (chiari) into which tidal water flows at high tide. In the fore front (upper part) there is a prevalence of Limonium narbonense, followed by Sarcocornia fruticosa and Spartina maritima (lower saltmarsh), with Zostera noltii in submersed areas; b) Tidal system environment. Landscape from the sea to the back barrier salt marsh across an outer sand bar (Martignano Island, Grado and Marano Lagoon, northern Adriatic Sea, Italy). The soil slopes down from the sand ridge forming a catena of soils characterized by different hydroperiods, but which will all be completely submersed during sygizal tides in spring and autumn. Photographs and descriptions: De Nobili M.

Fig. 9. Terrestrial environments. a) Mull system environment (humus form: Dysmull) in a sub-atlantic oak-hornbeam forest (Paimpont forest, France); b) Amphi system environment (humus form: Eumesoamphi) in a Mediterranean holm oak forest grazed by goats (Orgosolo, Sardinia, Italy).

Fig. 10. Anthropogenic environments. a) Mosaic of Agro system environments in Sardinia, Italy (during a field excursion of the Humus group in June 2006); b) Agro Mull in Legnaro (University of Padua, Italy), that has been ploughed after 5 years of grassland, prepared for a new experimental crop; c) Agro system in urban environment, under a gate of a pavement in Paris (France).

Fig. 11. Soil-free Techno humus system in a compost bin. It is possible to artificially create microclimate conditions (temperature and humidity) favourable to bioactivity thereby accelerating organic detritus decomposition. Organic matter is transformed by natural microbial and faunal processes but diagnostic horizons of natural humus systems are no longer observable. Biogenic structures (animal faeces as organic aggregates) appear as in a natural humus system, with undecayed litter at the top and newly generated organic horizons (if entirely closed or in contact with a concrete basement) or organic-mineral horizons (if in close contact with an underlying mineral soil horizon) at the bottom of the bin.

Fig. 12. Biomacrostructured $A$ horizon from a beech forest (Fontainebleau forest, France), shared with sieves in aggregates of varying size: from left to right $\leq 1 \mathrm{~mm},>1-4 \mathrm{~mm},>4 \mathrm{~mm}$. Such a type of horizon is present in Mull and Amphi humus systems. In the present case, the absence of an $\mathrm{OH}$ horizon indicates that the humus system is a Mull.

Fig. 13. Common tools used for field humus investigations: a) sieves ( $1 \mathrm{~mm}, 4 \mathrm{~mm})$; b) digital scale for the estimation of weight (volume) of bio-aggregates; $\mathrm{c}$ ) colorimetric estimation of $\mathrm{pH}_{\text {water; }}$ d) and e) tools used for the preparation of humus profiles; f) field key of classification and Munsell soil colour chart. 


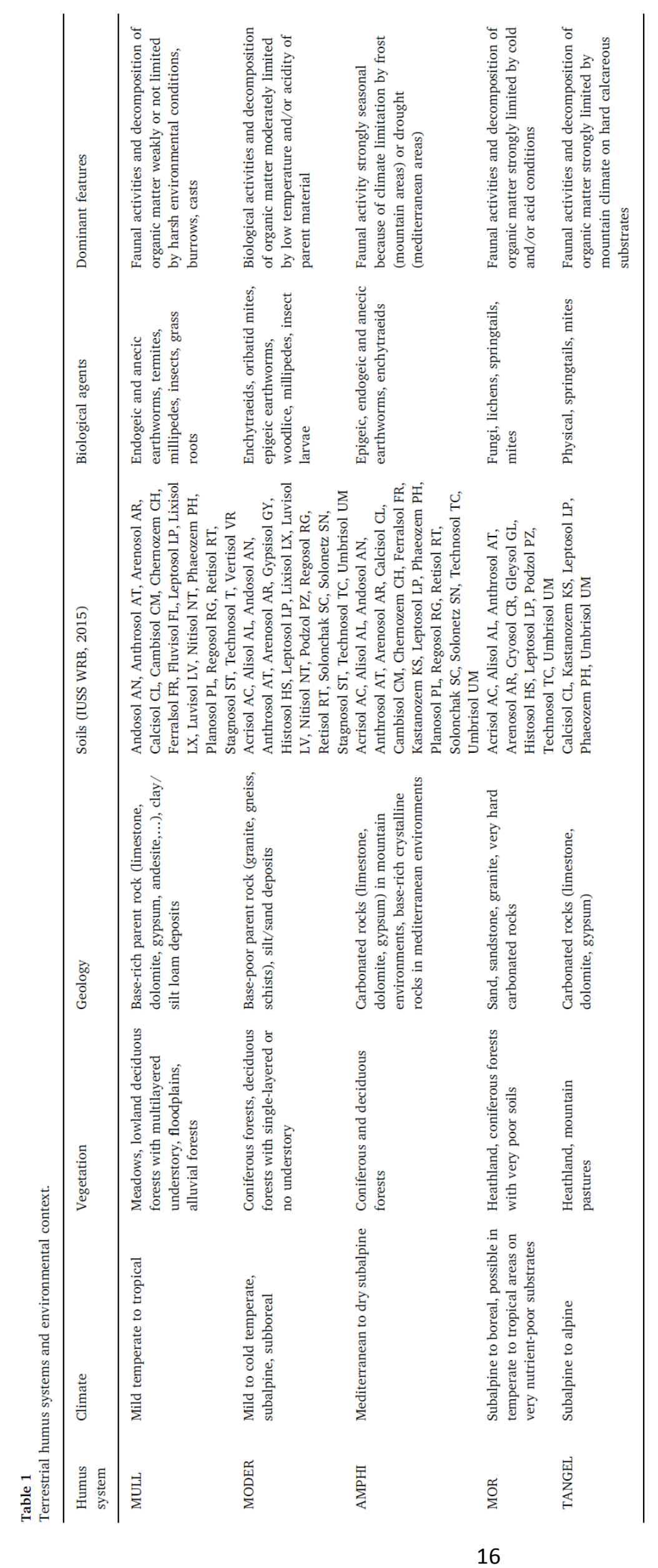




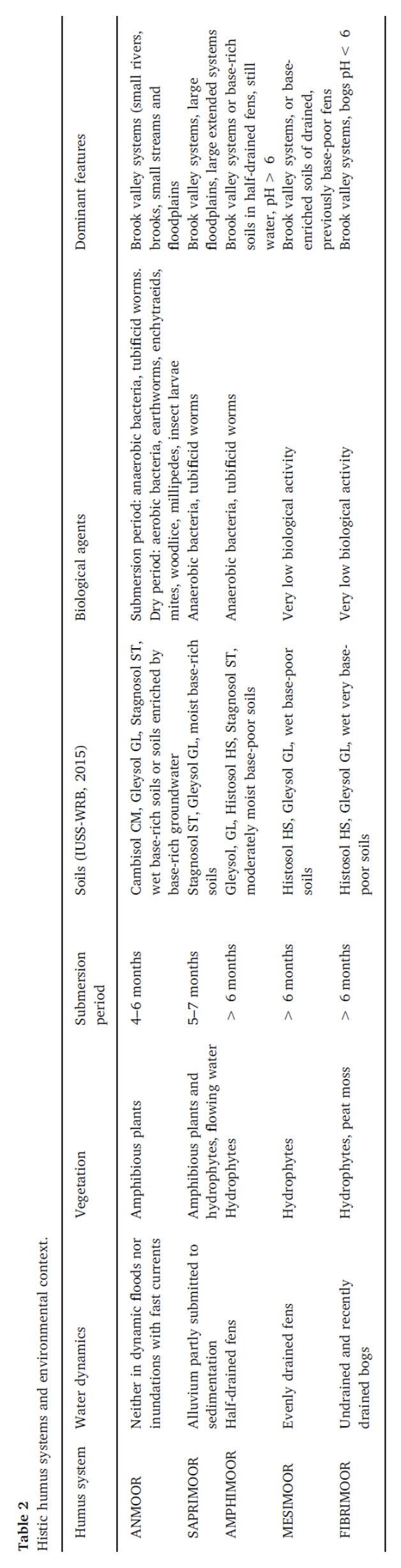


Table 3

Aqueous humus systems and environmental context. Oxitidal and Reductitidal have been suggested as two successive sub-systems along a gradient of decreasing oxygen availability (see Fig. 4) but they were not erected to the humus system level, in the absence of clear-cut passage from the one to the other. Thus only two main Aqueous humus systems are presented here, Tidal (Oxitidal and Reductitidal) and Subtital.

\begin{tabular}{|c|c|c|c|c|c|c|}
\hline $\begin{array}{l}\text { Humus } \\
\text { system }\end{array}$ & Water dynamics & Vegetation & Submersion period & Soils (IUSS-WRB, 2015) & Biological agents & $\begin{array}{l}\text { Dominant } \\
\text { features }\end{array}$ \\
\hline Tidal & Daily tide & $\begin{array}{l}\text { Amphibious plants, } \\
\text { Carex, Limonium, } \\
\text { Spartina... }\end{array}$ & 5-7 months & $\begin{array}{l}\text { Cryosol CR, Arenosol AR, } \\
\text { Fluvisol FL, Gleysol GL, } \\
\text { Stagnosol ST, Solonchar } \\
\text { SL }\end{array}$ & $\begin{array}{l}\text { Submersion period: anaerobic } \\
\text { bacteria, tubificid worms. Dry } \\
\text { period: aerobic bacteria, } \\
\text { earthworms, enchytraeids, mites, } \\
\text { woodlice, millipedes, insect } \\
\text { larvae, snails, slugs }\end{array}$ & High tidal zone \\
\hline Subtidal & $\begin{array}{l}\text { Exceptionally } \\
\text { emerged }\end{array}$ & No plants & $>11$ months & Arenosol AR, Solonchar SL & Anaerobic bacteria, Archaea & $\begin{array}{l}\text { Submersed } \\
\text { coastal zone }\end{array}$ \\
\hline
\end{tabular}


Table 4

Para humus systems and environmental context.

\begin{tabular}{|c|c|c|c|}
\hline Humus system & Description & Diagnostic characters & Dynamic considerations \\
\hline CRUSTO & $\begin{array}{l}\text { Biologically complex mosaic of } \\
\text { cyanobacteria, green algae, lichens, } \\
\text { mosses, microfungi, and/or other bacteria } \\
\text { (thickness from mm to a few } \mathrm{cm} \text { ). }\end{array}$ & $\begin{array}{l}\text { Soil and microorganisms form a compact } \\
\text { 3D-aggregate. The presence of soil } \\
\text { distinguishes biological rock crusts } \\
\text { (micro-crusts, established on rock) from } \\
\text { biological soil crusts (macro-crusts, } \\
\text { established on soil). Rock crusts evolve } \\
\text { into soil crusts once and if enough soil } \\
\text { material has accumulated. }\end{array}$ & $\begin{array}{l}\text { Pioneer ecosystems of arid and polar deserts, } \\
\text { rocky outcrops and walls, harsh climate, } \\
\text { nutrient and moisture conditions, incipient } \\
\text { stages of soil development. }\end{array}$ \\
\hline BRYO & $\begin{array}{l}\text { Mosses or arbuscular lichens or small } \\
\text { stonecrop plants totally covering the soil } \\
\text { and forming a stratified carpet or cushion } \\
\text { with living (green) parts overgrowing a } \\
\text { layer of dead stems and leaves. }\end{array}$ & $\begin{array}{l}\text { Humus systems where more than } 90 \% \text { of } \\
\text { volume (estimated in the field by naked } \\
\text { cye) of cumulated OL and OF horizons is } \\
\text { made of moss. }\end{array}$ & $\begin{array}{l}\text { Pioneer ecosystems succeeding to biological } \\
\text { crusts in cold, arid or peat environments; } \\
\text { also in mosaic on boulders or under forest } \\
\text { trees on eroded soil. }\end{array}$ \\
\hline RHIZO & $\begin{array}{l}\text { Organic and/or mineral-organic layers } \\
\text { almost entirely made of root material } \\
\text { (living and dead). }\end{array}$ & $\begin{array}{l}\text { Humus systems where more than } 50 \% \text { of } \\
\text { volume (estimated in the field by naked } \\
\text { eye) of the cumulated humus profile is } \\
\text { made of roots or other subterranean plant } \\
\text { parts. }\end{array}$ & $\begin{array}{l}\text { Heathland and grassland ecosystems built by } \\
\text { grass, fem, ericaceous and other } \\
\text { suffrutescent or scrub vegetation, with very } \\
\text { active development of subterranean parts. }\end{array}$ \\
\hline LIGNO & $\begin{array}{l}\text { Organic diagnostic horizons almost } \\
\text { entirely made of wood decayed by fungi } \\
\text { and tunneled by invertebrates }\end{array}$ & $\begin{array}{l}\text { Humus systems where more than } 90 \% \text { of } \\
\text { volume (estimated in the field by naked } \\
\text { eye) of cumulated organic horizons is } \\
\text { made of more or less decayed wood }\end{array}$ & $\begin{array}{l}\text { Specific ecosystems exploiting the energy } \\
\text { released during wood decomposition. The } \\
\text { process of decomposition takes place on the } \\
\text { ground or on stems and branches still on } \\
\text { standing dead trees. Very common in old- } \\
\text { growth forests, particularly in unmanaged } \\
\text { temperate and tropical forests. }\end{array}$ \\
\hline ANAERO & $\begin{array}{l}\text { Humus system under the prominent } \\
\text { influence of anaerobic bacteria in } \\
\text { submersed anoxic photic habitats } \\
\text { (exposed to sunlight and permitting } \\
\text { photosynthesis). }\end{array}$ & $\begin{array}{l}\text { River, lake marsh and sea beds, sewage } \\
\text { beds... }\end{array}$ & $\begin{array}{l}\text { Extremophile habitats without any } \\
\text { successional development due to very harsh } \\
\text { and instable conditions. Considered as a first } \\
\text { stage of a more evolved Aqueous. }\end{array}$ \\
\hline ARCHAEO & $\begin{array}{l}\text { Humus system under the prominent } \\
\text { influence of archaea or anaerobic bacteria, } \\
\text { cyanobacteria, microfungi or microalgae } \\
\text { in emerged photic or submersed aphotic } \\
\text { extreme habitats. }\end{array}$ & $\begin{array}{l}\text { Extremophile habitats without plants; } \\
\text { highly saline, acidic, or alkaline water; hot } \\
\text { springs; wet surfaces of any type, } \\
\text { supporting organic matter or other sources } \\
\text { of energy; areas surrounding volcanoes, } \\
\text { fumaroles, deep dark aphotic seas } \\
\text { (barophile miciroorganisms)... }\end{array}$ & $\begin{array}{l}\text { Pioneer organic humus systems associated } \\
\text { with incipient soil formation. In dry habitats, } \\
\text { they may evolve into Crusto, in humid } \\
\text { habitats into Bryo humus systems. }\end{array}$ \\
\hline
\end{tabular}


Table 5

Anthropogenic systems: description, diagnostic characters, dynamic considerations.

\begin{tabular}{|c|c|c|c|}
\hline Humus system & Description & Diagnostic characters & Dynamic considerations \\
\hline AGRO & $\begin{array}{l}\text { Humus system, more or less modified } \\
\text { by man but still assignable to a } \\
\text { functionally similar natural reference. } \\
\text { Agricultural humus systems or less } \\
\text { artificial urban humus systems. }\end{array}$ & $\begin{array}{l}\text { Lying on mineral soil. At least one humus } \\
\text { horizon (organic or organic-mineral) } \\
\text { recognizable and amenable to a } \\
\text { functionally similar natural reference. } \\
\text { Tillage profile or managed dump of } \\
\text { organic remains. }\end{array}$ & $\begin{array}{l}\text { Agricultural fields, market and kitchen } \\
\text { gardens, not strongly altered urban } \\
\text { humus systems (under trees or in } \\
\text { shrubby areas). }\end{array}$ \\
\hline \multirow[t]{3}{*}{ TECHNO } & $\begin{array}{l}\text { Manure Humus: Man-made humus } \\
\text { systems, with recognizable horizons } \\
\text { assignable to comparable natural } \\
\text { humus horizons; compost or mulch, } \\
\text { other artificial organic or mineral- } \\
\text { organic mixtures. }\end{array}$ & $\begin{array}{l}\text { Man-made humus systems mimicing } \\
\text { natural systems, with natural materials } \\
\text { and soil; humus horizons generally } \\
\text { recognizable even if animal and microbial } \\
\text { communities are impoverished compared } \\
\text { to natural humus systems. }\end{array}$ & $\begin{array}{l}\text { Used to restore strongly exploited soils, } \\
\text { increase their content in organic matter } \\
\text { and their biodiversity. }\end{array}$ \\
\hline & $\begin{array}{l}\text { Soil-free Humus: Man-made humus } \\
\text { systems without humus horizons } \\
\text { visible by the naked eye; nutriculture, } \\
\text { hydroponic cultures without soil. }\end{array}$ & $\begin{array}{l}\text { Artificial humus systems without organic } \\
\text { or organic-mineral soil horizons; the use of } \\
\text { inert media (gravel, sand, sawdust, rock } \\
\text { wool, coco coir, peat, vermiculite, perlite, } \\
\text { pumice, rice hulls, other soil-free } \\
\text { mixtures...) is common and soil formation } \\
\text { is avoided. }\end{array}$ & $\begin{array}{l}\text { Greenhouse production, sunlight and } \\
\text { artificial lightning, vertical vegetable } \\
\text { and fruit production, use of treated } \\
\text { wastewater... }\end{array}$ \\
\hline & $\begin{array}{l}\text { Dump Humus: Man-made humus } \\
\text { systems corresponding to waste } \\
\text { deposits with humus horizons not } \\
\text { assignable to known Terrestrial, } \\
\text { Histic, Aqueous or Para natural humus } \\
\text { horizons. }\end{array}$ & $\begin{array}{l}\text { Organic matter under decomposition, but } \\
\text { so rich in artefacts or waste materials or } \\
\text { technic materials that it is impossible to } \\
\text { recognize a natural humus horizon or } \\
\text { system. }\end{array}$ & $\begin{array}{l}\text { Landfills, waste heaps, industrial waste, } \\
\text { very altered urban humus systems. More } \\
\text { or less uncontrolled sewage sludge, toxic } \\
\text { waste, landfill waste, masonry waste, } \\
\text { topsoil abandoned to recycling of waste } \\
\text { and biodegraded materials. }\end{array}$ \\
\hline
\end{tabular}




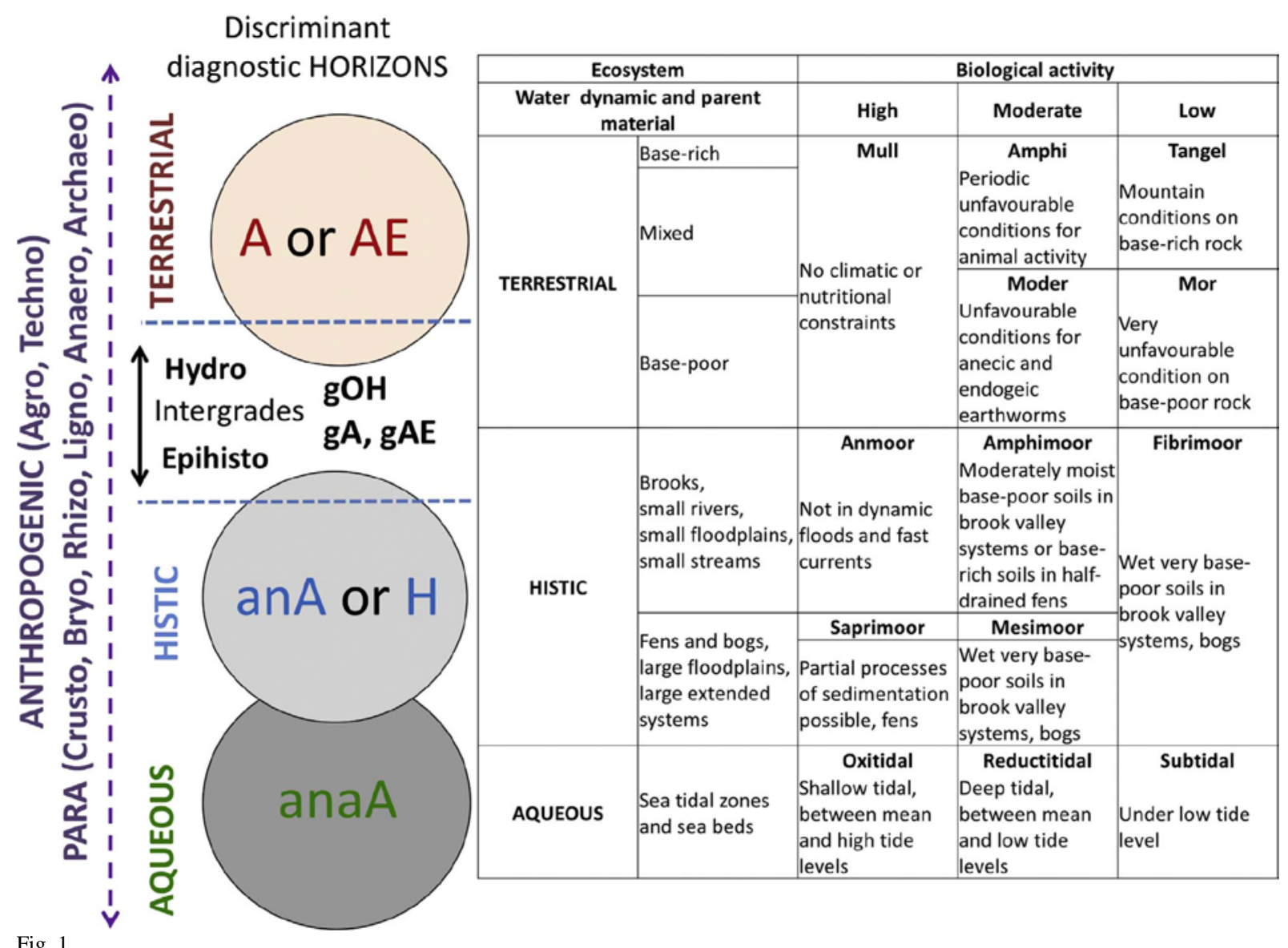




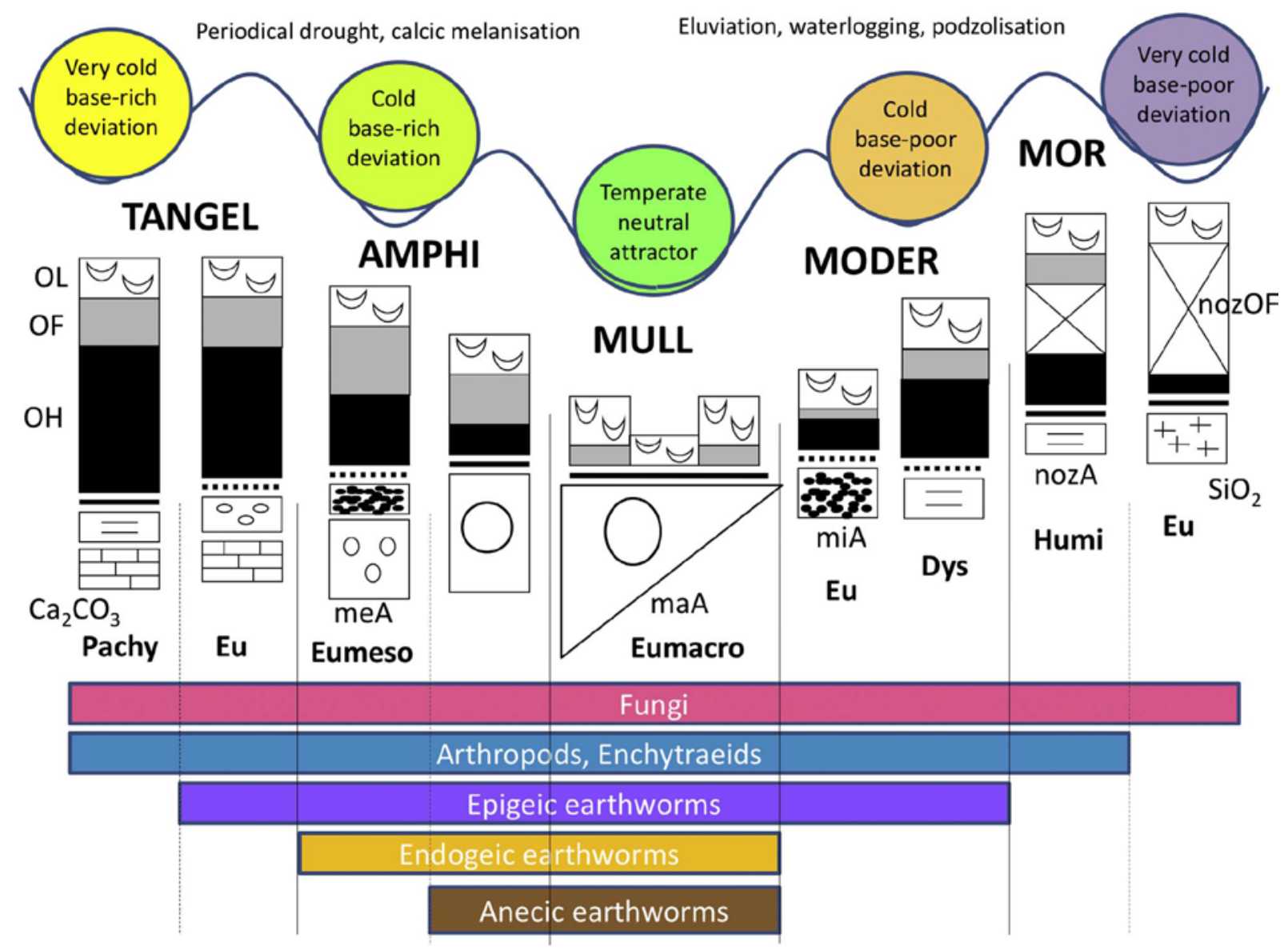

Fig. 2 


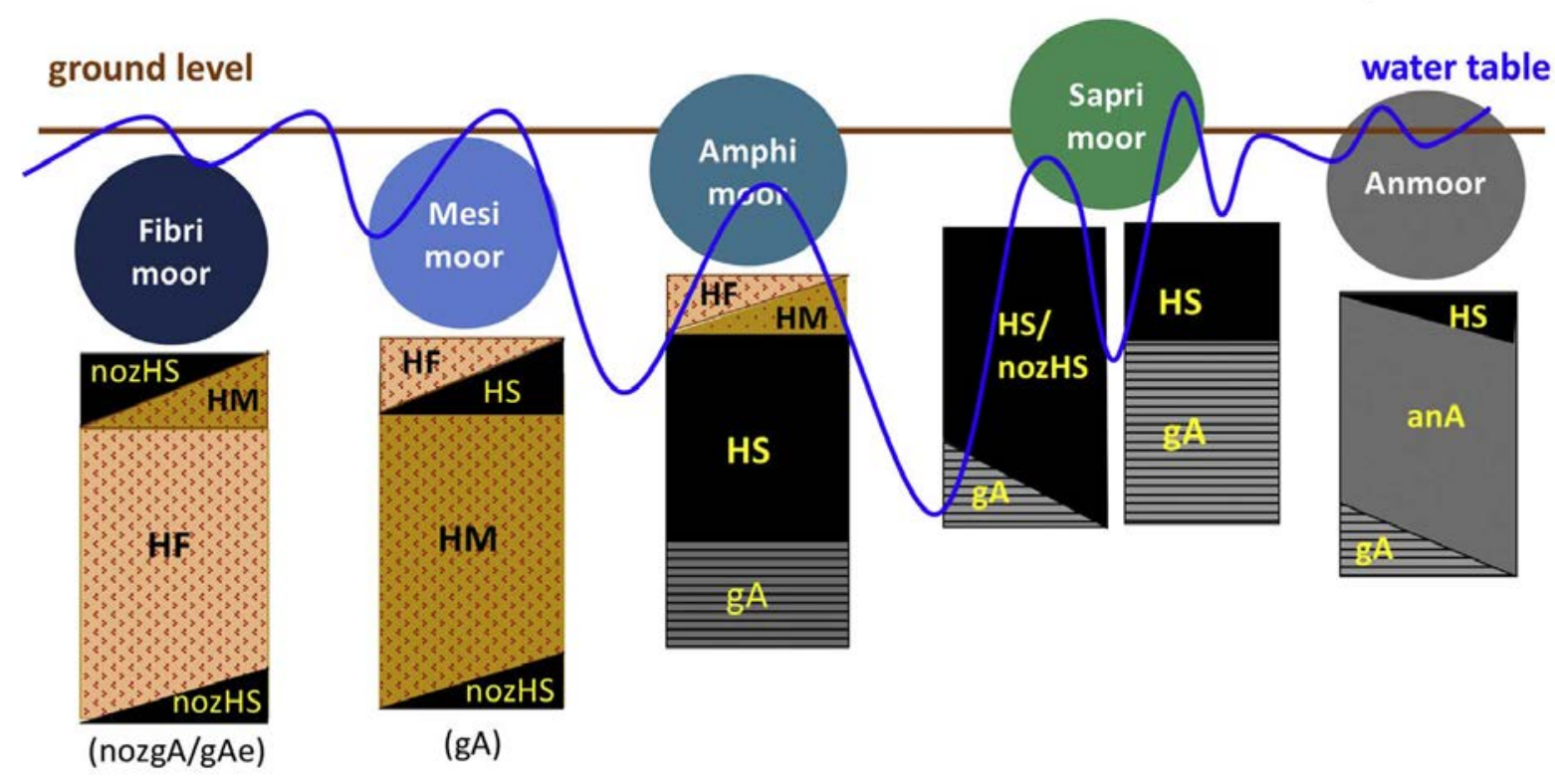

Very low bioactivity

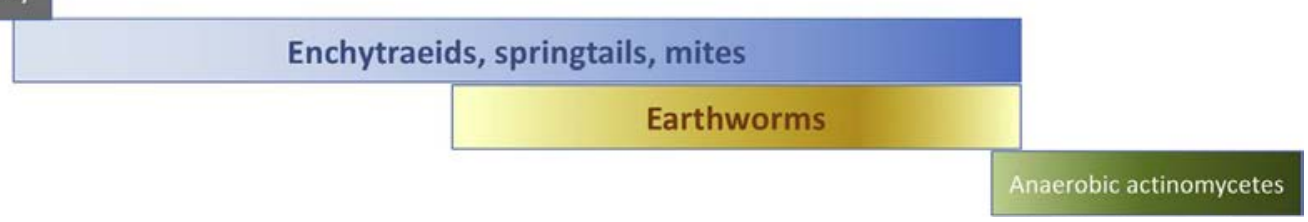

Fig. 3 
Plants: marine algae, amphibious plants, Juncus, Limonium,

Spartina, Sacocornia, Mangrove species...

\begin{tabular}{|c|c|c|c|}
\hline \multirow{2}{*}{ Horizons } & \multicolumn{2}{|r|}{ TIDAL } & SUBTIDAL \\
\hline & Oxitidal & Reductitidal & Eusubtidal \\
\hline $\mathbf{0}$ & 10YR $2 / 1$ & 10YR $2.5 / 1$ & $5 G Y 3 / 1 ; N 2.5 / 1$ \\
\hline anaA & $\begin{array}{l}\text { 10YR 7/2; } 10 \text { YR 4/1; } 2.5 \text { Y } 2.5 / 1 ; \\
2.5 Y 4 / 2\end{array}$ & $\begin{array}{l}10 Y R \text { 5/2; } 10 Y 3 / 1 ; \text { N } 2.5 / 1 ; 10 Y 4 / 1 ; 5 Y \\
5 / 1 ; N \text { N } 3 / 1\end{array}$ & $10 \mathrm{~B} 2 / 4 ; 10 \mathrm{GY} 4 / 1 ; \mathrm{N} 2.5 / 1$ \\
\hline A/C; A/B & 10YR $4 / 1$ & N $2.5 / 1 ; 10 Y 4 / 1$ & $10 \mathrm{~B} 3 / 1 ; \mathrm{N} 5 / 1$ \\
\hline OC & 10YR6/12.5Y 5/1 & $10 Y R 4 / 2 ; \mathrm{N} 3 / 1 ; \mathrm{N} 7 / 1$ & $5 B G 2.5 / 1 ; 5 B G 4 / 1$ \\
\hline \multirow[t]{6}{*}{ C } & N 5/1; N 6/1 & N 7/1; $10 Y$ 4/1; N 4/1; 5 G 5/1 & $\begin{array}{l}\text { 5BG 2.5/1; } 5 \text { GY } 6 / 1 ; \text { N 5/1; } 10 G Y 3 / 1 ; \\
10 G Y 4 / 1 ; 10 \text { GY } 8 / 1\end{array}$ \\
\hline & \multicolumn{2}{|c|}{ Enchytraeids, springtails, mites } & \\
\hline & \multicolumn{2}{|c|}{ Earthworms } & \\
\hline & & \multicolumn{2}{|c|}{ Tubificid worms, clams } \\
\hline & \multicolumn{2}{|c|}{ Aerobic bacteria } & \\
\hline & & \multicolumn{2}{|c|}{ Anaerobic bacteria and archaea } \\
\hline
\end{tabular}

Fig. 4 


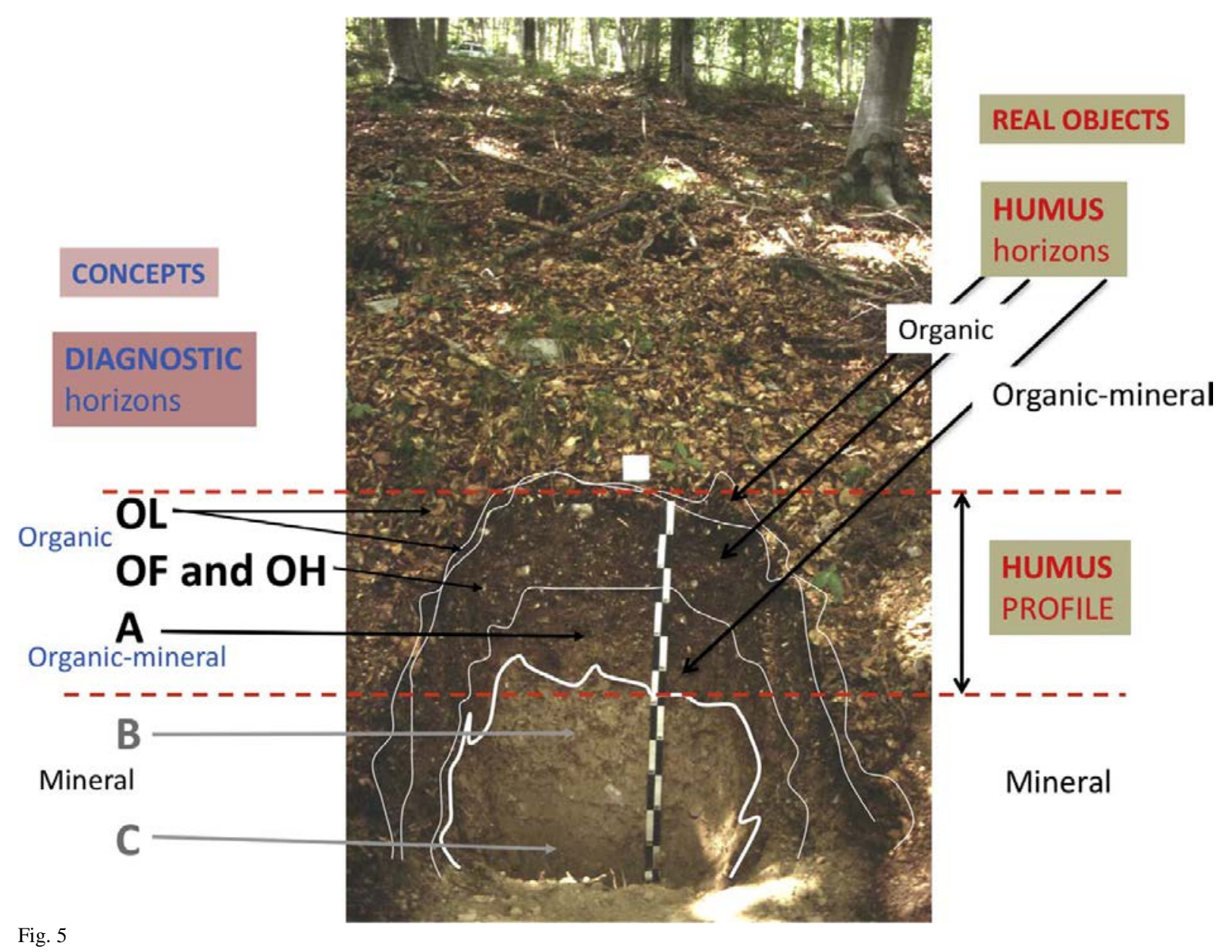


A

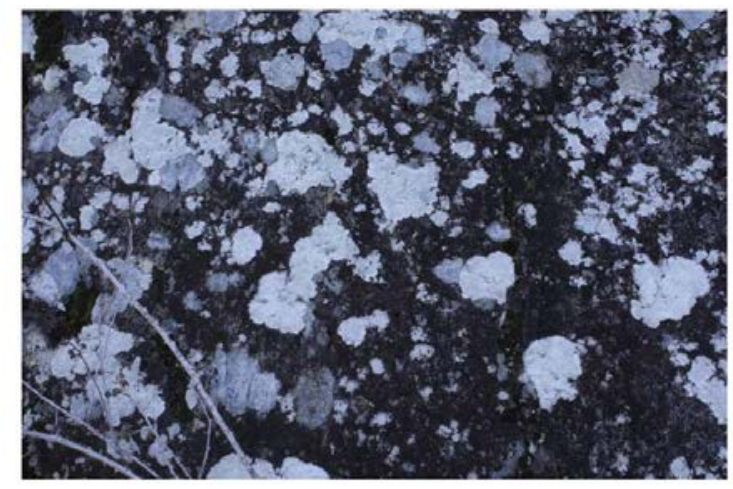

B

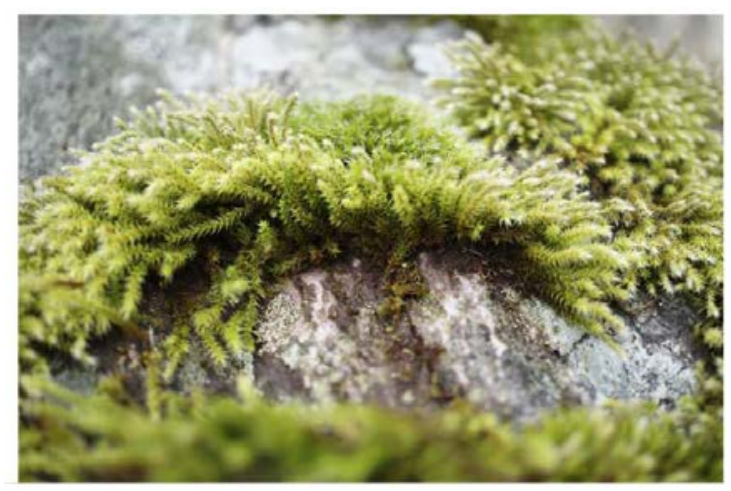

C

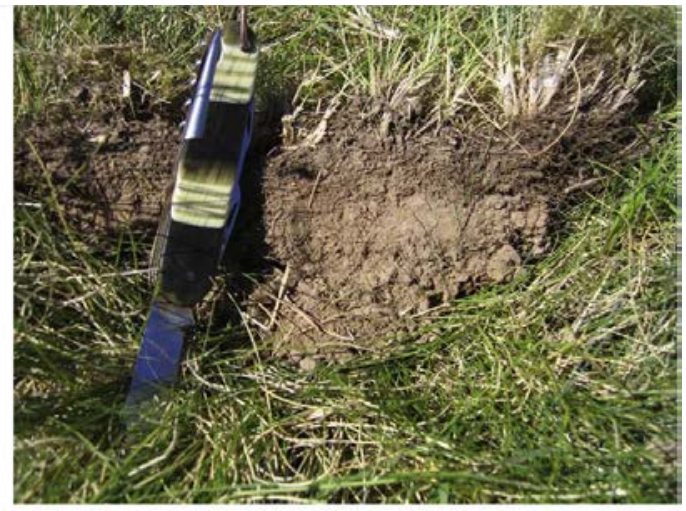

D

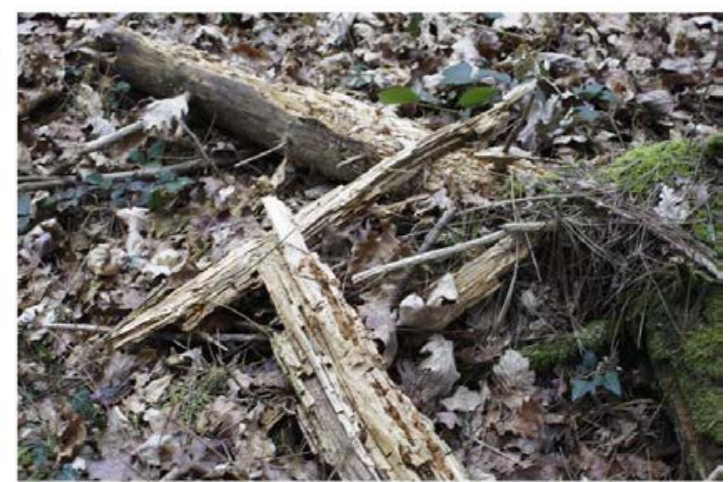

Fig. 6 


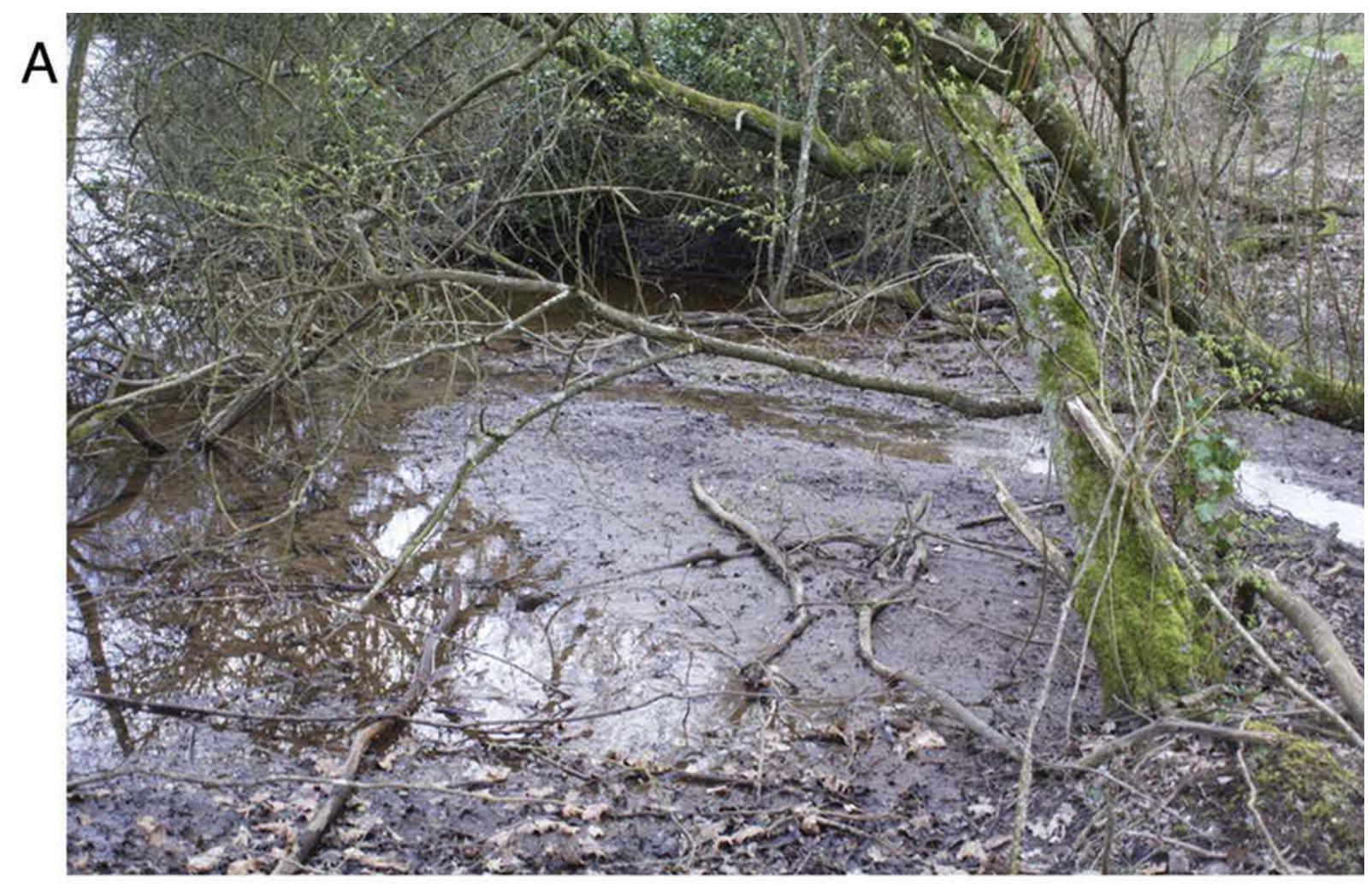

B

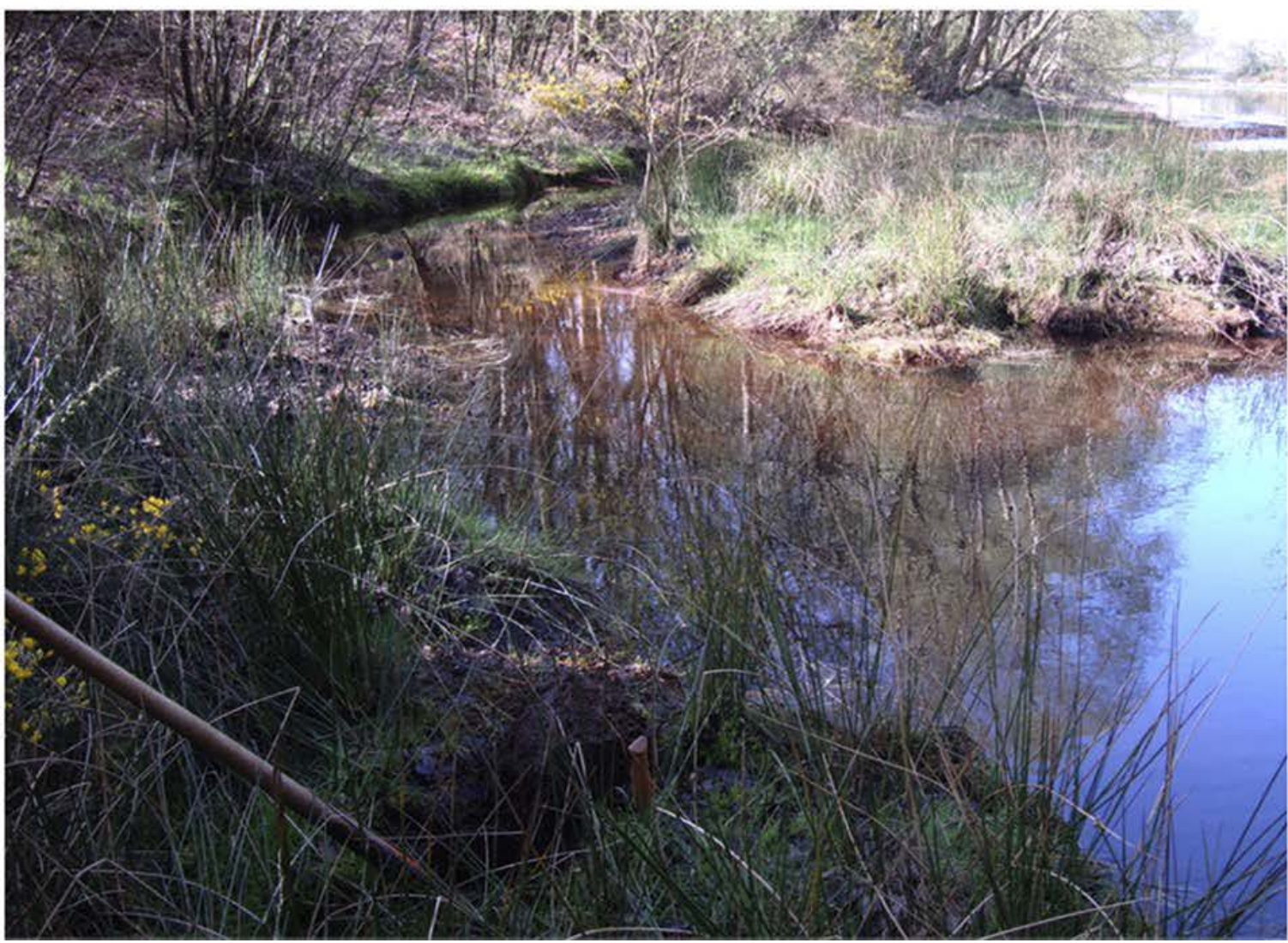

Fig. 7 


\section{A}

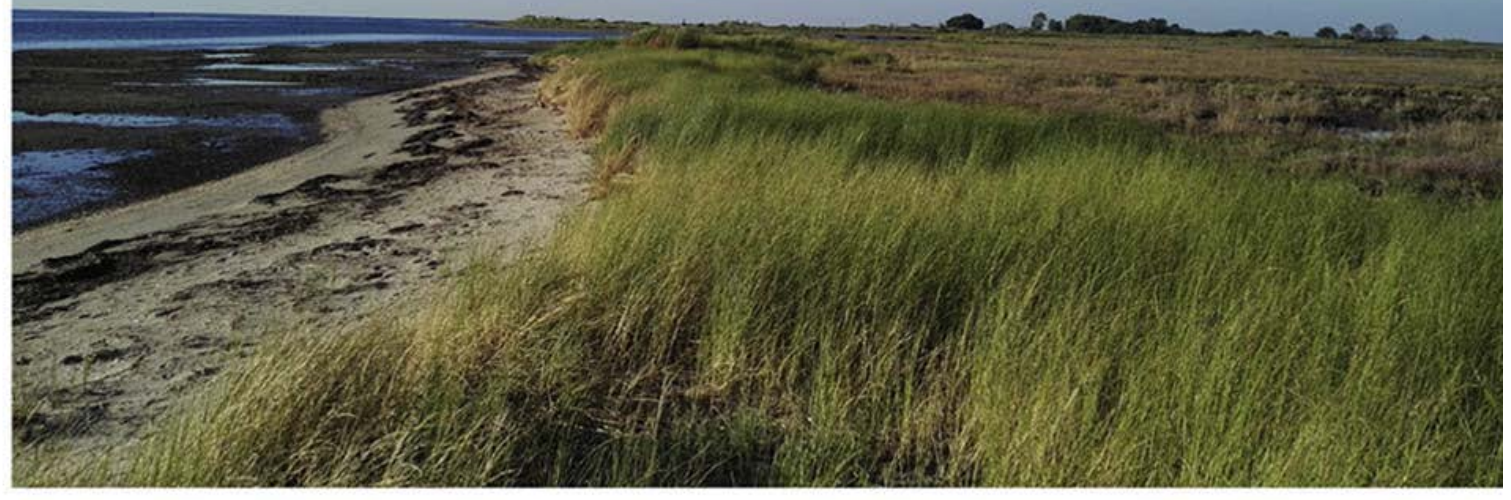

B

Fig. 8

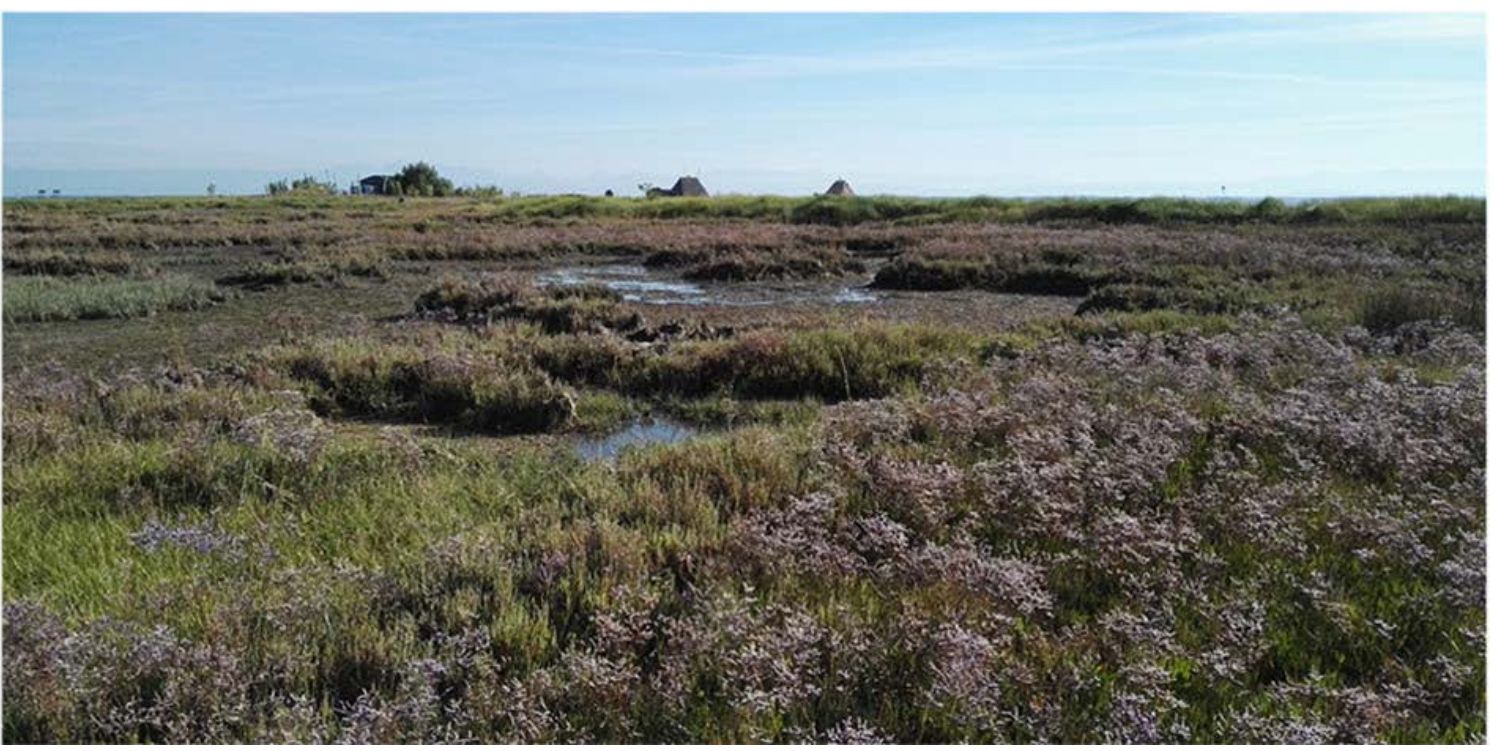



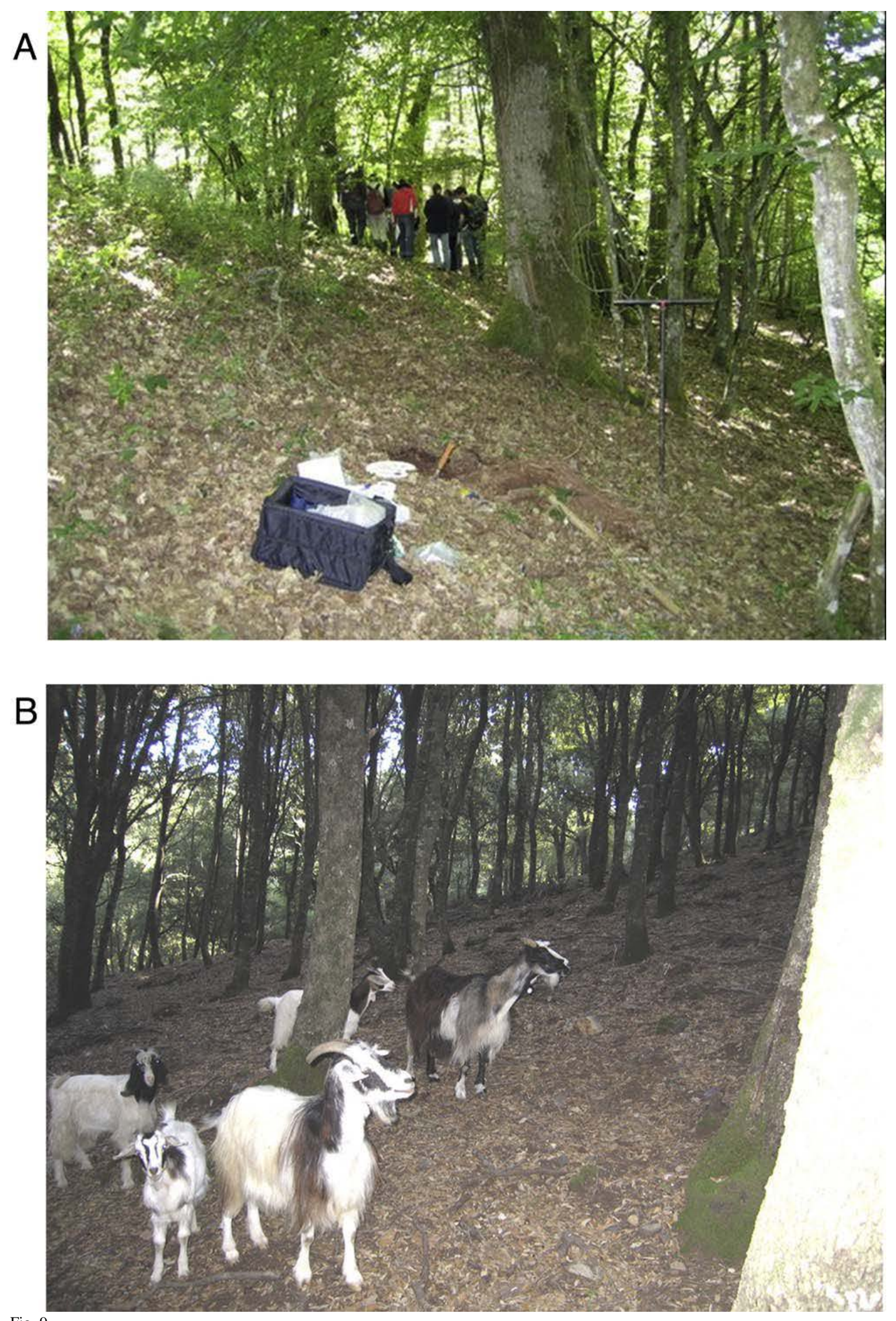

Fig. 9 
A

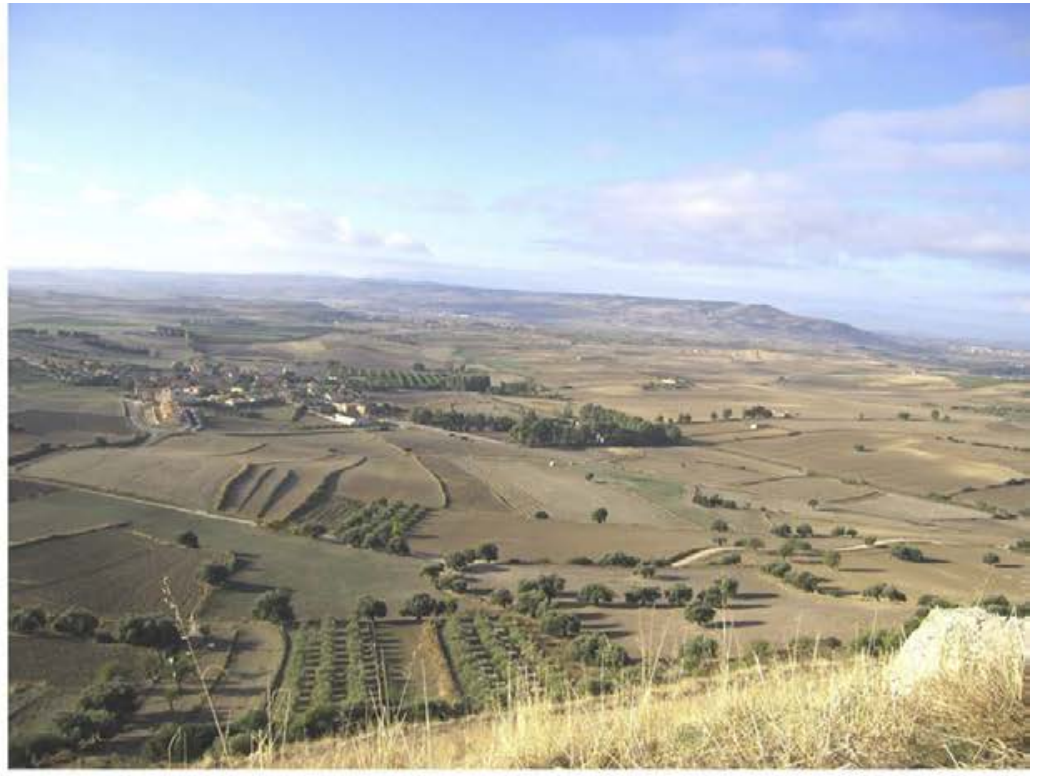

B

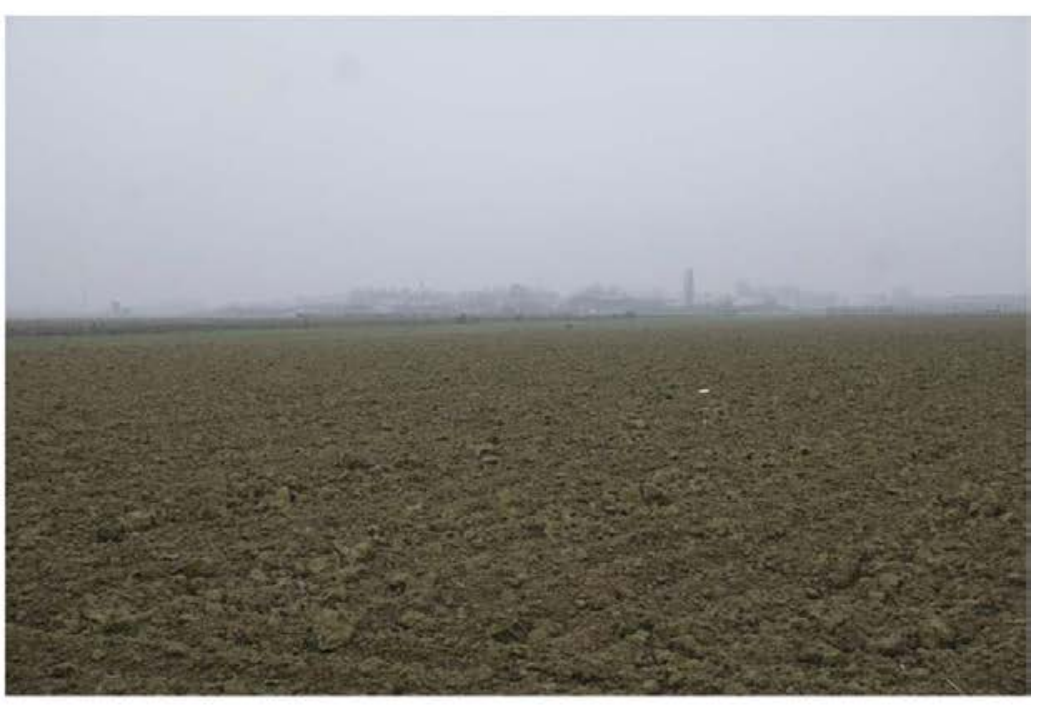

C

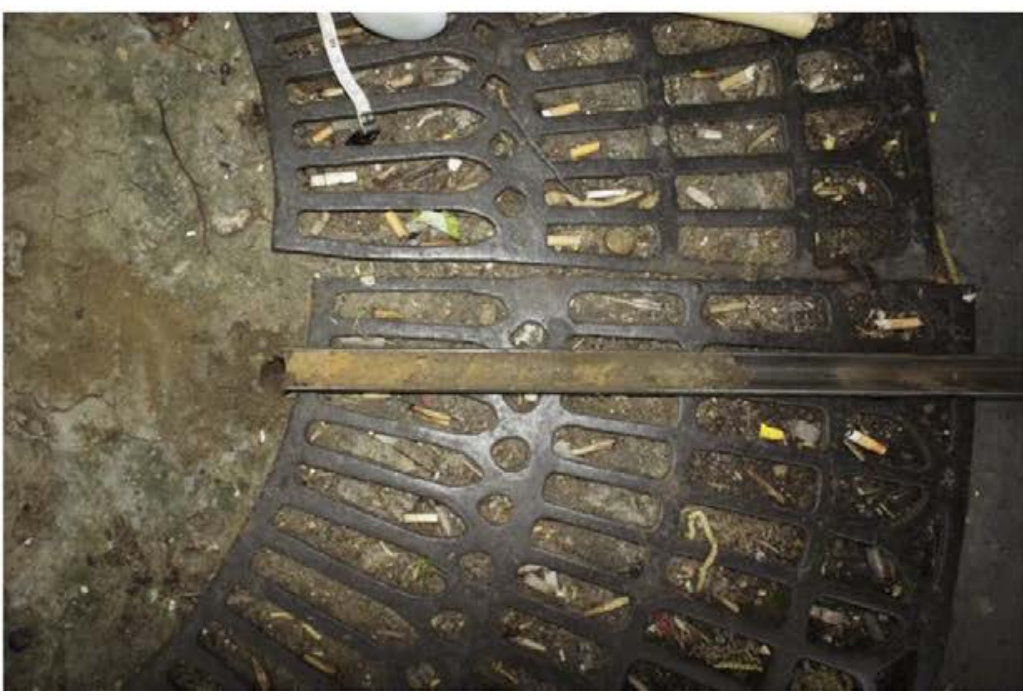

Fig. 10 


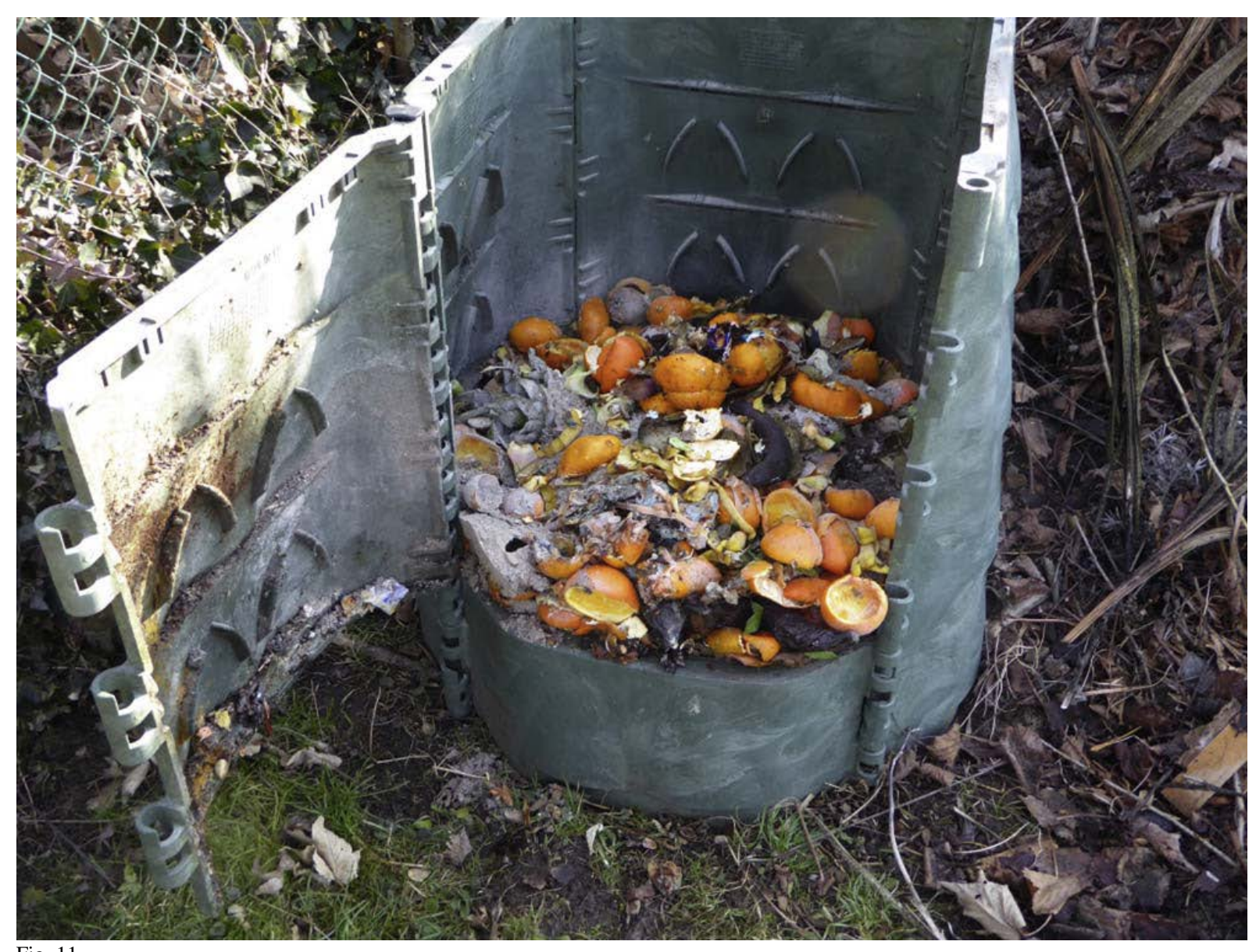

Fig. 11 


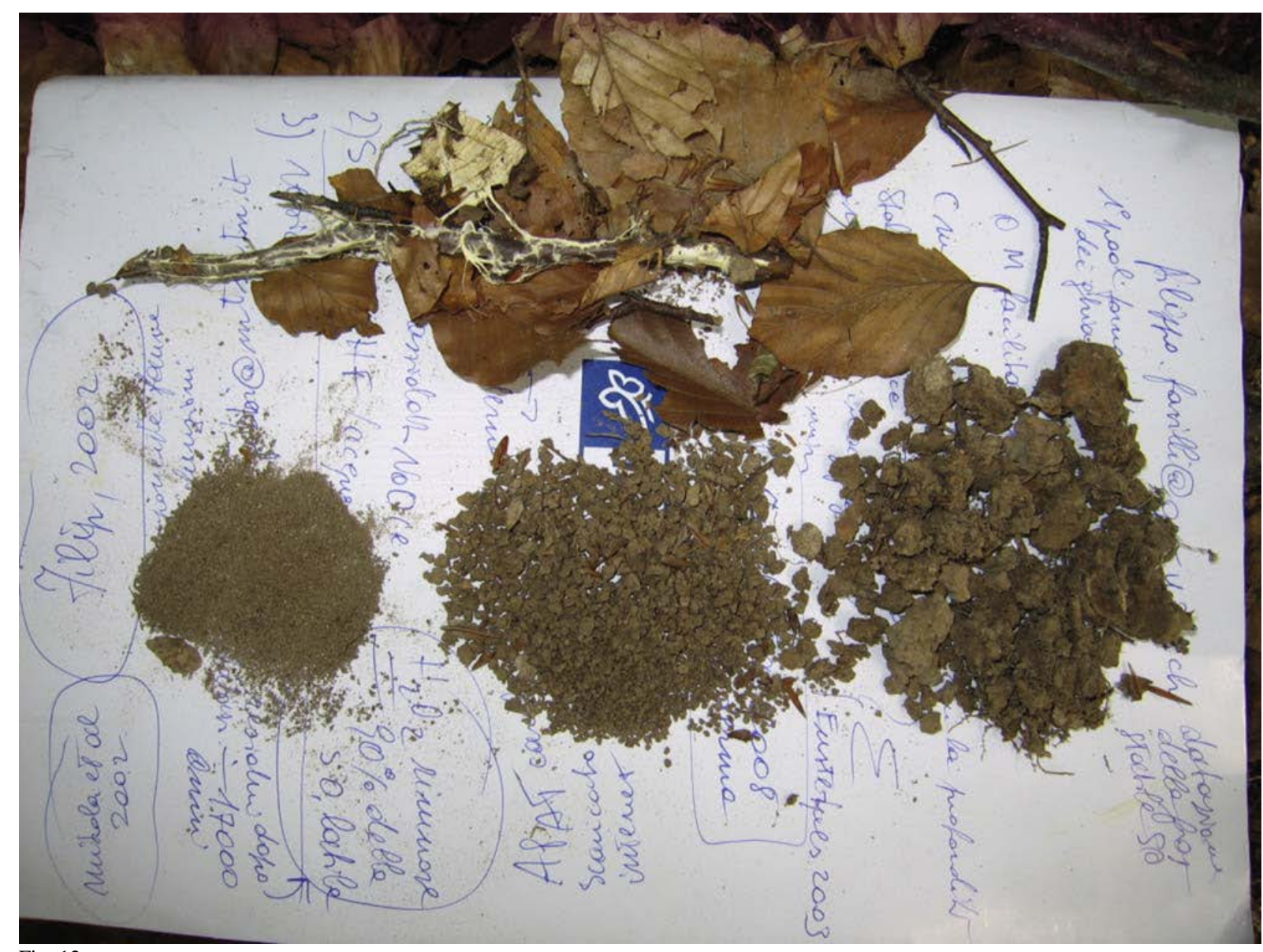

Fig. 12 

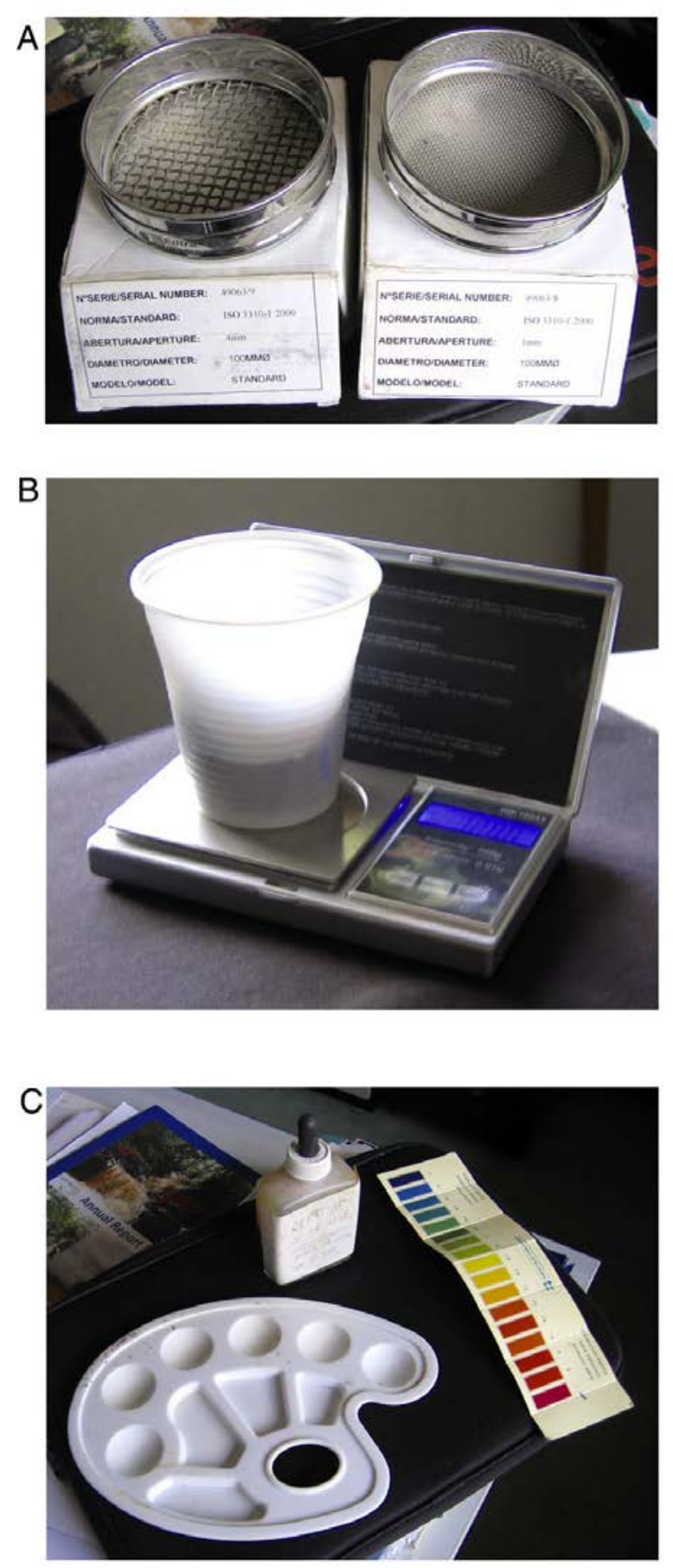

Fig. 13

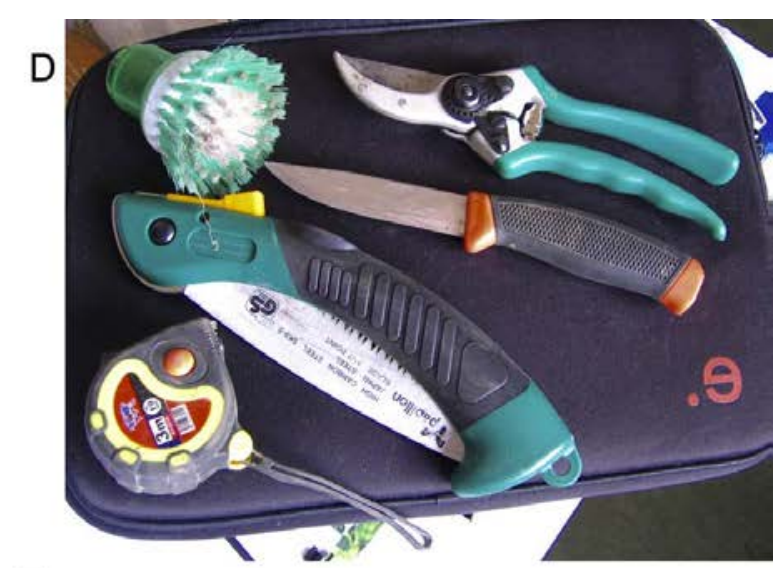

E

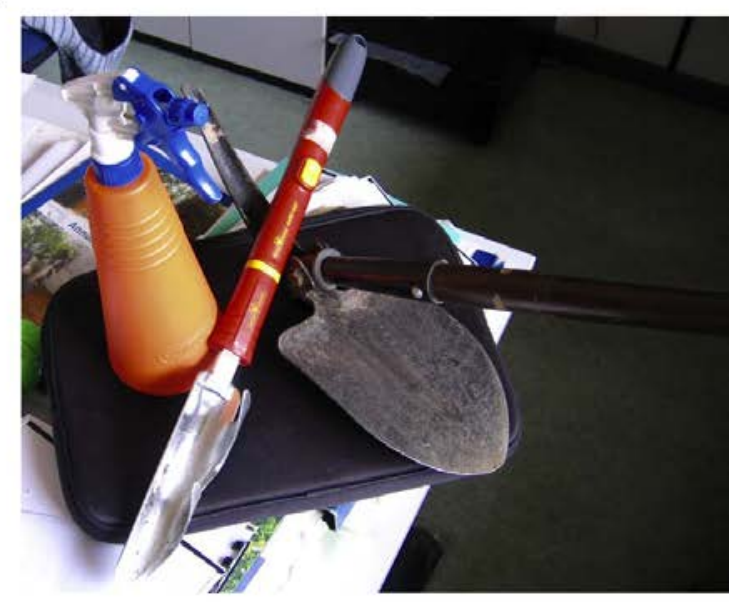

F

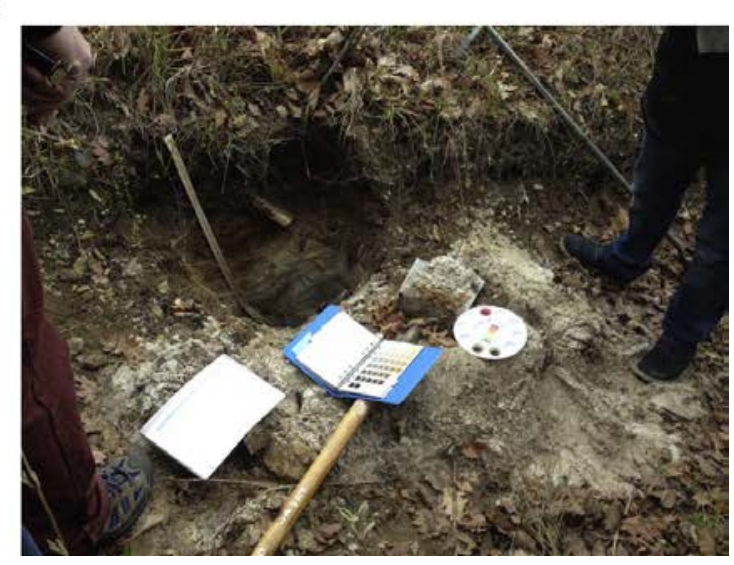

